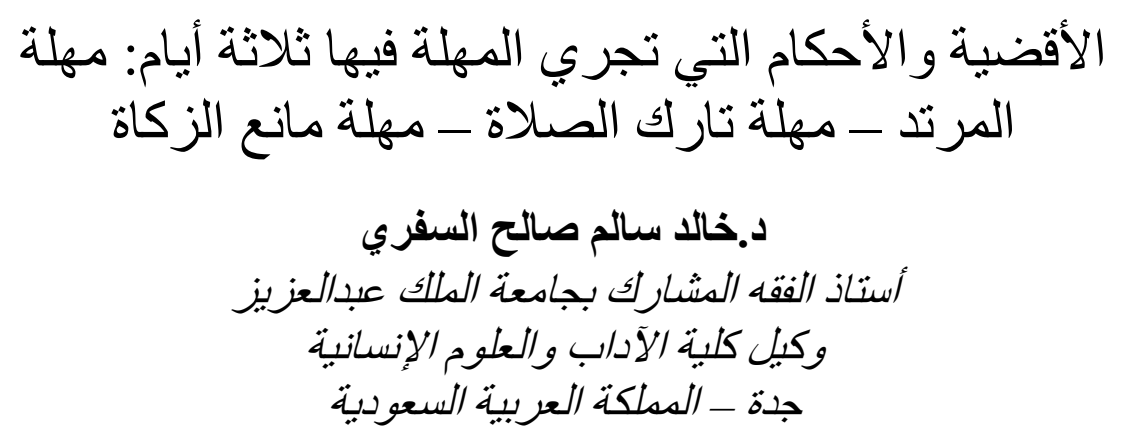

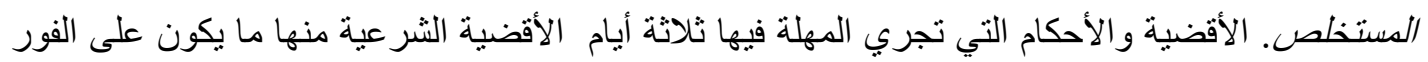

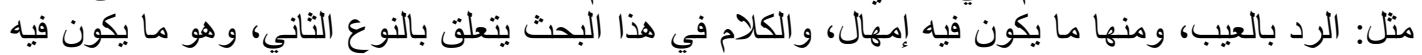

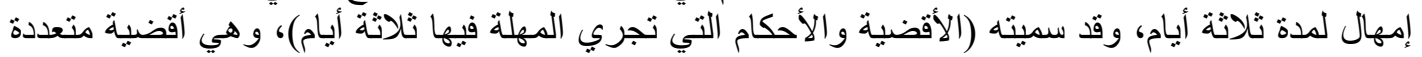

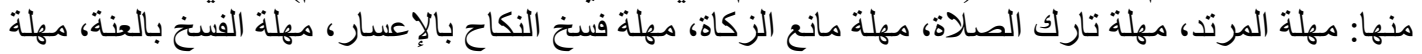

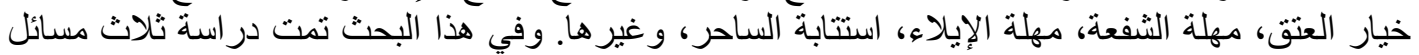

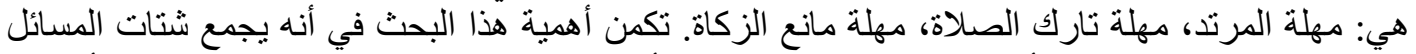

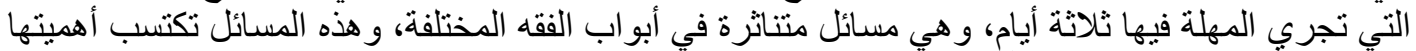

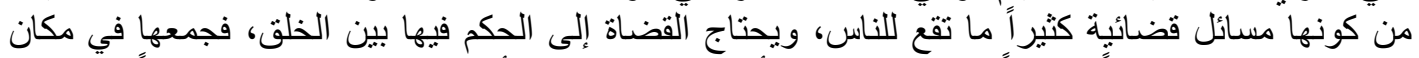

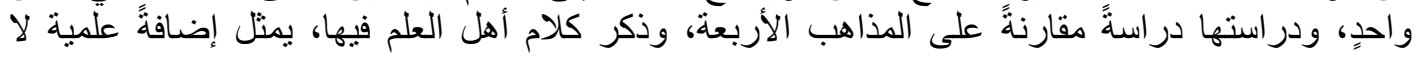
يستغني عنها القاضي الثر عي. درالئ

أيام)، وهي كثيرة منها: مهلة المرتد، مهلة تارك كائك

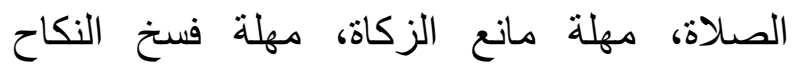
بالإعسار، مهلة الفسخ بالعنة، مهلة خيار العنق،

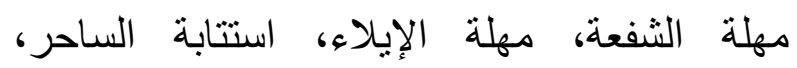
و وغير ها.

وفي هذا البحث سأقوم بدراسة ثلاث مسائل هي: مهلة المرتد، مهلة تارك الصلاة، مهلة مانع الزكاة.

\section{أهمية الموضوع الهرتون}

تكمن أهمية هذا البحث في أنه يجمع شتات المسائل

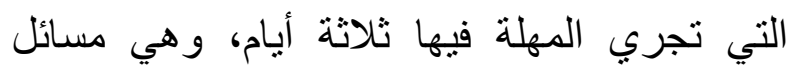
متناثرة في أبواب الفقه المختلفة، وهذه المئل وهائل

\section{مقدمة}

إن الحمد الله نحمده ونستعينه ونستغفره، ونعوذ بالله

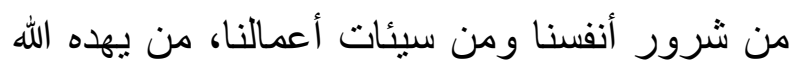

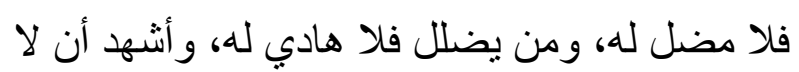

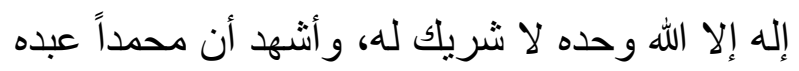
ورسوله، وبعد. فإن الأقضية الثر عية منها ما يكون على الفور مثل:

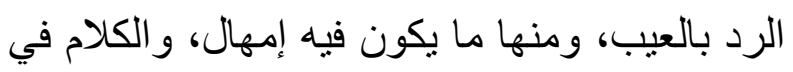

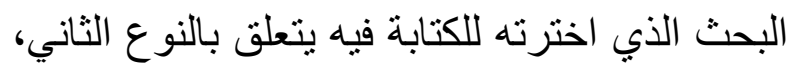

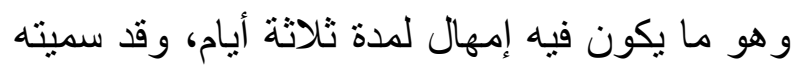
(الأقضية والأحكام التي تجري المهلة فيها ثلاثة 
المطلب السادس: الترجيح. رابعاً: المبحث الثالث: مهلة تارك الزكاة، وفيه ستة مطالب. المطلب الأول: تعريف الزكاة لغةً. المطلب الثاني: تعريف الزكاة اصطلاحاً. المطلب الثالث: تحرير محل النزاع في مهلة مانع

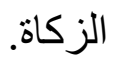
المطلب الر ابع: سبب الخلاف في المسألة. المطلب الخامس: الأدلة. المطلب السادس: الترجيح. خامساً: الخاتمة، وقد لخصت فيها أهم النتائج التي توصلت إلبها من خلال البحث وبعض التوصيات التي رأيتها. سادساً: الفهارس، وقد ختمت البحث بفهارس تيسر لقارئ البحث الوصول إلى محتوياته، وقد تضمنت الفهارس: فهرساً للآيات القرآنية، والأحاديث

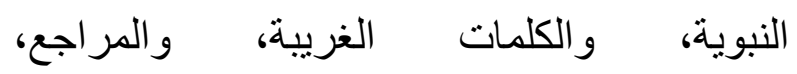
ولموضو عات البحث. منهج البحث 1- جمعت المسائل الفقهية التي ذكر الفقهاء رحمه الله- الإمهال فيها ثثلاثة أيام، ولم ألتزم

$$
\text { بمذهب دون غيره. }
$$

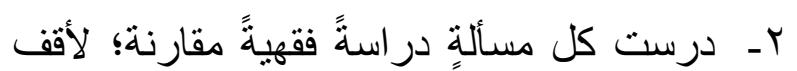
على مذاهب أهل العلم في المسألة، وأهم الأدلة التي استدل بها أصحاب المذاهب المختلفة. r- التزمت الترجيح في نهاية كل مسألة.

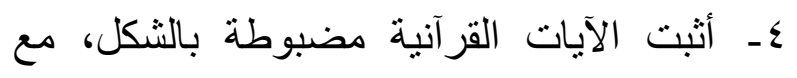
ذكر اسم السورة ورقم الآية في الأصل.
تكتسب أهميتها من كونها مسائل قضائية كثيراً ما تقع للناس، ويحتاج القضاة إلى الحكم فيها بين الخلق، فجمعها في مكان واحدٍ، ودر استها دراسةً مقارنةً على المذاهب الأربعة، وذكر كلام أهل العلم فيها، يمثل إضافةً علمية لا يستغني عنها القاضي التهي الثرعي. خطة البحث يتكون البحث من مقدمة وثلاثة مباحث، وخاتمة ثم

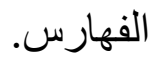
أولاً: المقدمة، وفيها بيان الموضوع، وأهميته، وخطة البحث، ومنهجه. ثانياً: المبحث الأول: مهلة استتابة المرتد، وفيه ستة مطالب: المطلب الأول: تعريف المهلة لغةً واصطلاحاً. المطلب الثاني: تعريف الردة لغةً و اصطلاحاً. المطلب الثالث: تحرير محل النزاع في مدة استتابة

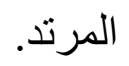
المطلب الر ابع: سبب الخلاف في إمهال المرتد من عدمه. المطلب الخامس: الأدلة و المناقشات. المطلب السادس: الترجيح. ثالثاً: المبحث الثاني: مهلة تارك الصلاة، وفيه ستة مطالب. المطلب الأول: تعريف الصلاة لغةً. المطلب الثاني: تعريف الصلاة اصطلاحاً. المطلب الثالث: تحرير محل النزاع في مهلة تارك

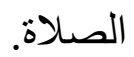
المطلب الر ابع: سبب الخلاف في المسألة. المطلب الخامس: الأدلة. 
المُهلة في اللغة: اسم من التَهْل بالسكون، وهو

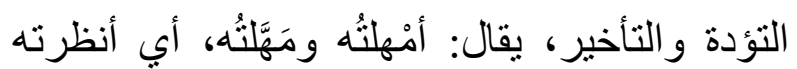

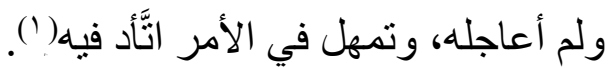

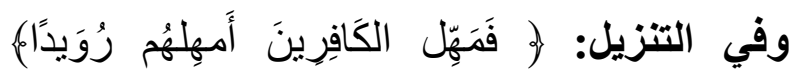

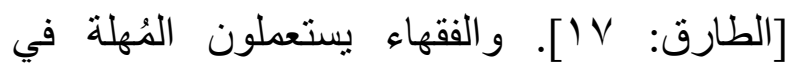

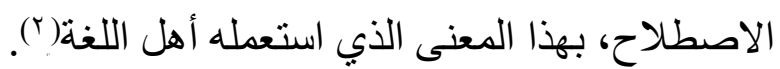

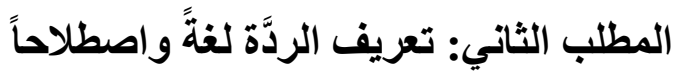
الرّّدة في اللغة بالكسر نأتي لثناثة أمور (ّ):

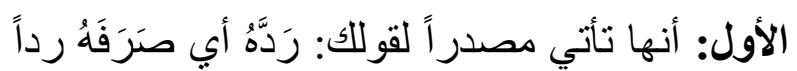
ورِدة، فهي مصدر رد المتعدي بمعنى صَرْفه، وهو متعد. الثاني: تأتي اسماً من الارتداد الذي هو الرجوع،

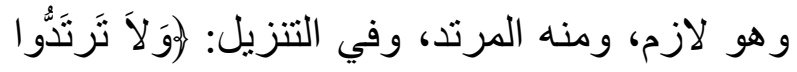

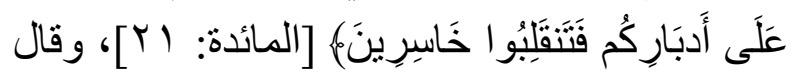

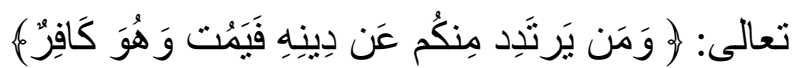

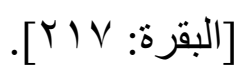

الثالث: تأتي بمعنى امتلاء الضرع

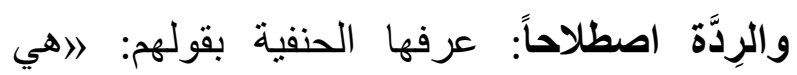

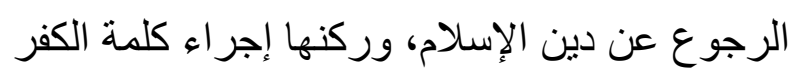

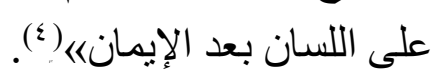

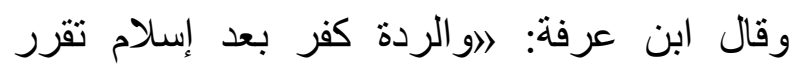

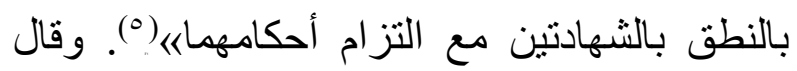

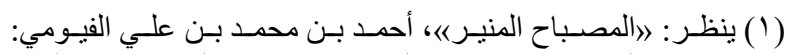

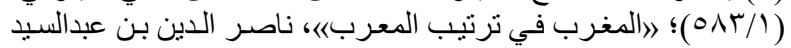

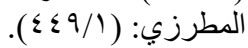

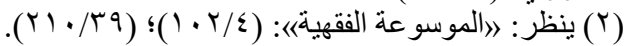

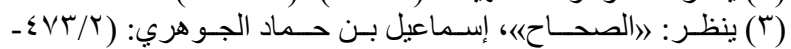

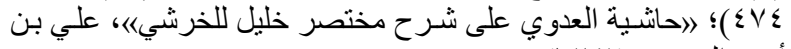

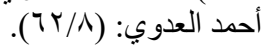

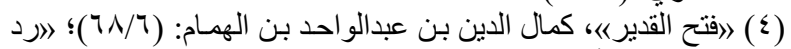

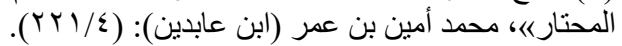

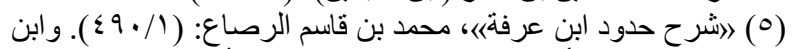

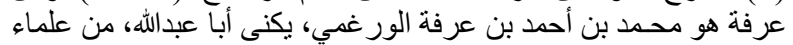

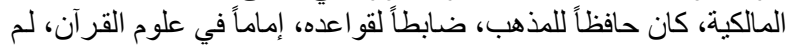
يرض لنفسه الدخول في الولايـة، بل اقتصــر على الإمامـة و الخطابـة
0ـ خرَّت الأحاديث النبوية الواردة في البحث، فإن كان الحديث الثريف في الصحيحين أو أحدهما، اكتفيت بذلك، وإلا خرجته من سائر المصنادر الحديثية مع بيان درجته عند أهل العلم. 7ـ قـت بعزو النصوص الواردة في البحث إلى دئه مر اجعها، فإن كنت نقلت النص حرفياً وضعته بين قوسين، وأثرت في الحاثنية إلى المرجع ورقم

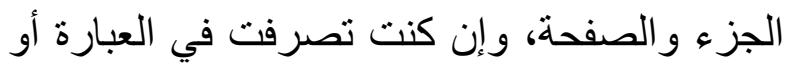
استقيت المعلومة، فإني أثثير في الحاثية بقولي (ينظر)، ثم أذكر اسم المرجع و الجزء و الصحفة. V- التزمت بترتيب المراجع في الحاثية الواحدة حسب التسلسل الزمني لوفاة مؤلفيها في الغالب وقدر الإمكان. A- التزمت توثيق الآراء الفقهية ومذاهب العلماء من الكتب المعتمدة لكل مذهب. 9 - رجعت إلى معاجم اللغة في التعريفات اللغوية. • ـ شرحت غريب الحديث و المصطلحات الفقهية. 1 ا ـوضعت فهارس عامة تشمل ما يلي: فهرس الآيات، فهرس الأحاديث النبوية، فهرس الآثار، فهرس الكلمات الغريبة، فهرس المراجع، الاحس، فهرس الموضو عات التفصيلي. وختاماً فإني أسأل الله أن يغفر لي ولو الدي ولذريتي ولمشايخي، وأن يسلك بي سبيل أهل العلم، وصلى ولى ولى ولئي

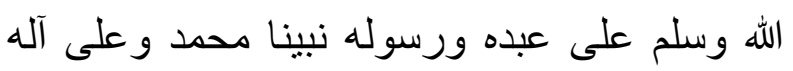
وصحبه أجمعين. و الحمد لله رب العالمين.

$$
\text { مهلة استتابة المرتد الأول }
$$

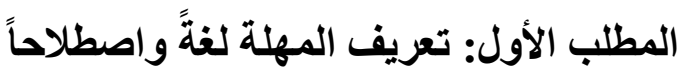


قبل قتله(م، ثم اختلف القائلون بالاستتابة في مدتها

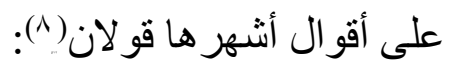
الأول: أن مدتها ثلاثة أيام، وهو هرونان مروي عن عمر بن

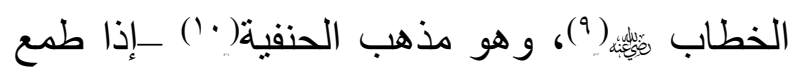
الإمام في توبته، أو سأل هو التأجيل- وبتأقيتها ثثلاثة

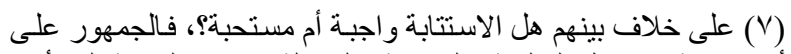

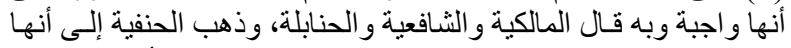

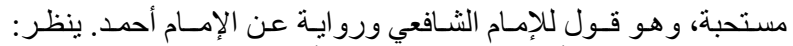

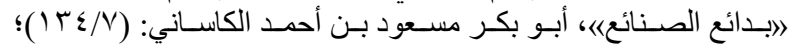

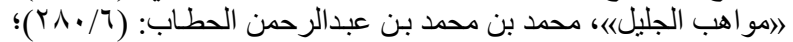

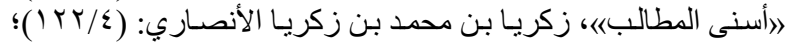

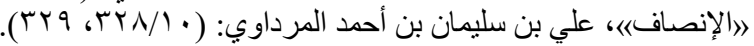

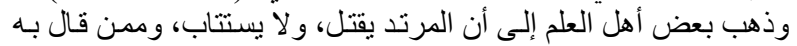

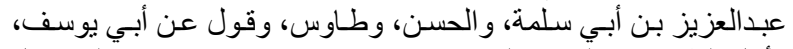

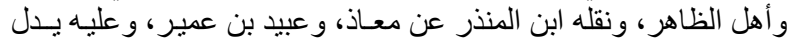

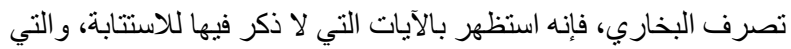

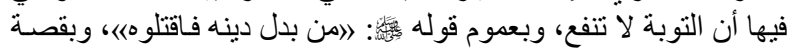

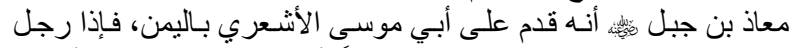

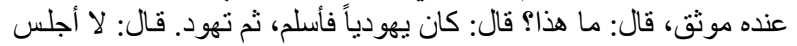

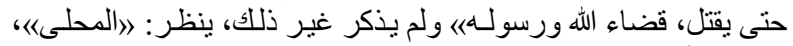

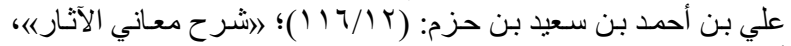

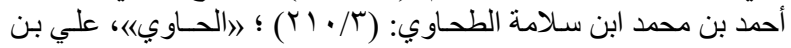

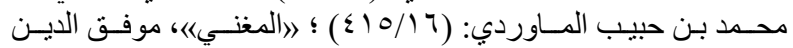

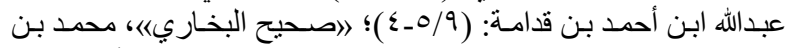

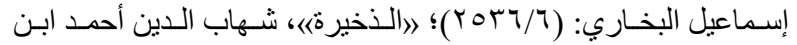

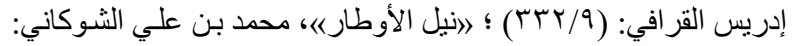

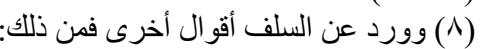

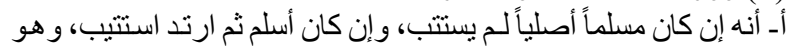

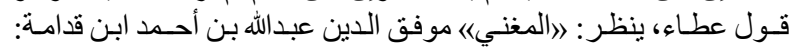

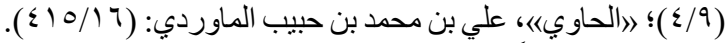

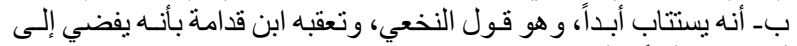

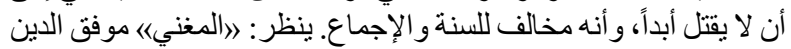

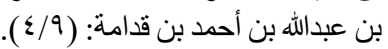

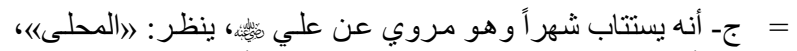

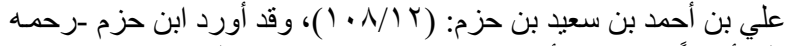

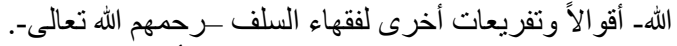

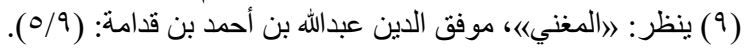

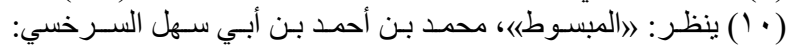

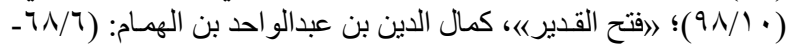

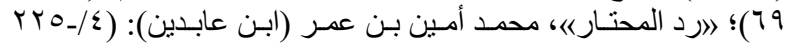

. (YMT
القر افي هي عبارة عن: ا(قطع الإسلام من مكلف إما باللفظ أو بالفعلی) (')

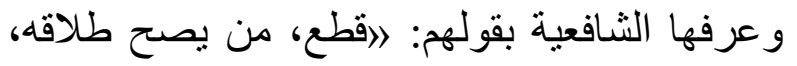

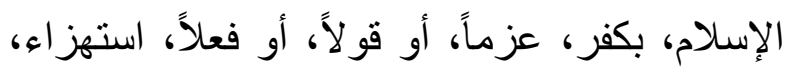

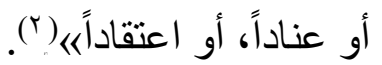

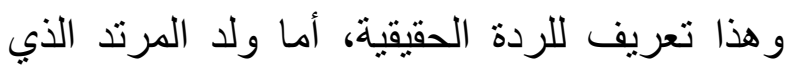

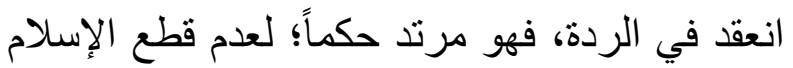

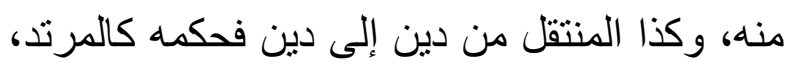

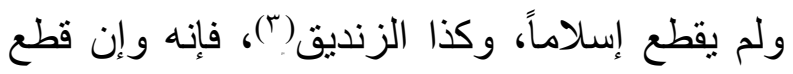

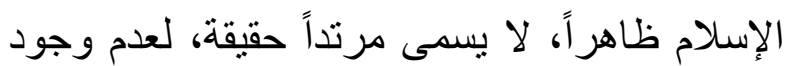

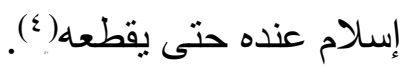

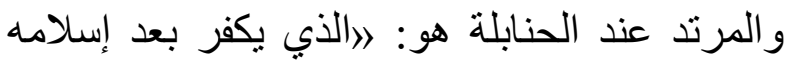

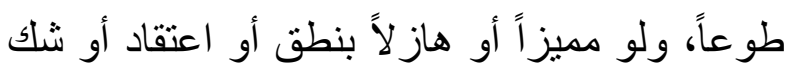

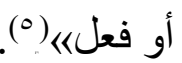

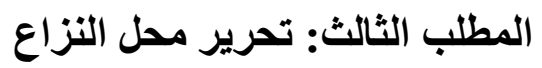

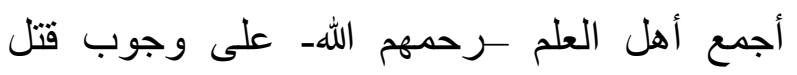
المرتد(") ما لم يتب، وذهب عامتهم إلى أنه يستناب

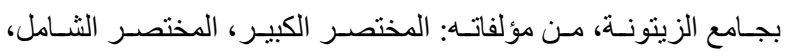

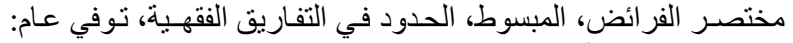

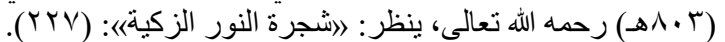

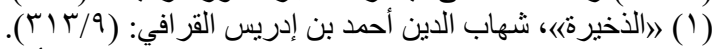

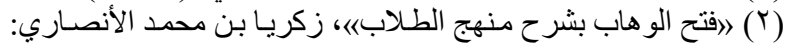

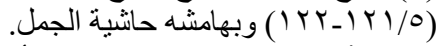

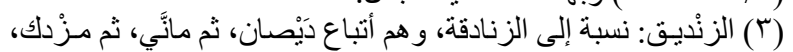

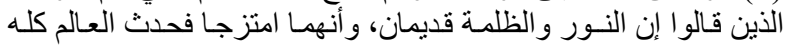

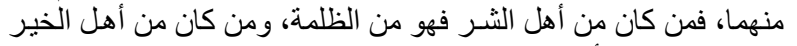

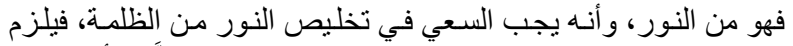

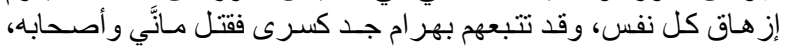

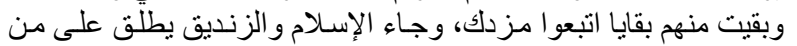

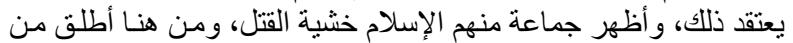

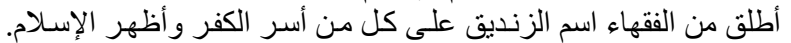

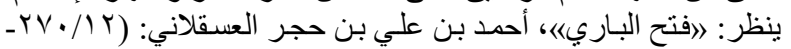
(YV) ( ) ينظر : (احاثية البجيرمي على شرح الخطيب)، سليمان بن عمر

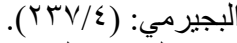

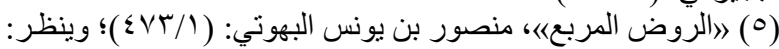

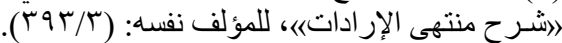

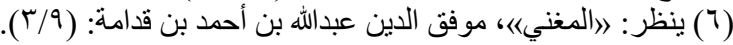


الأمر بالقتل، بعد الاستتابة والإمهال ثثلاثاً للآثار الأخرى الواردة في المسألة.

\section{المطلب الخامس: الأدلة والمناقشات}

استدل الجمهور لمذهبهم في أن المرتد يستتاب ثناثة

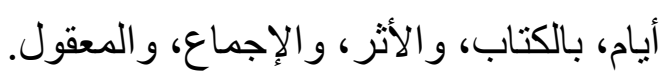

أولاً: الكتاب: ل الكتاب:

قول الله تبارك وتعالى عن قوم صالح: لوفَعَقَرُوهَا

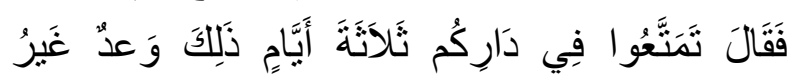

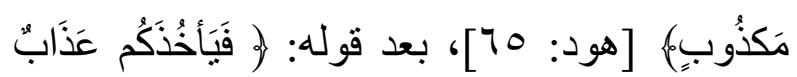

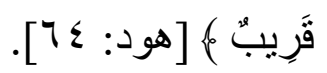

وجه الالالة: أن الله تعالى قد أوعد بعذاب قريب، أنظَرَ فيه ثناثاً؛ فكان هذا الإنظار في الأحكام أولى لَّلى منه في العذاب المحتوم(9).

\section{ثانياً: الأثر}

ما رو اه الإمام ماللك في الموطأ أن رجلاً قدم على الأز عمر بن الخطاب نِئه: من قبل أبي موسى الأشعري

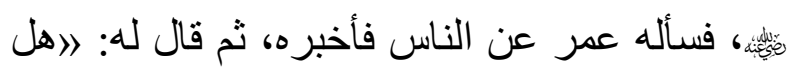
كان فيكم من مُغْرِبة خبر (·(1)؟ فقال: نعم رجل كفر

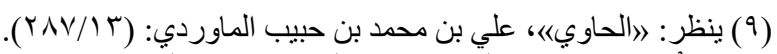

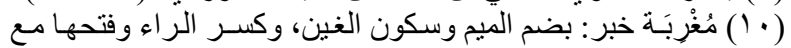

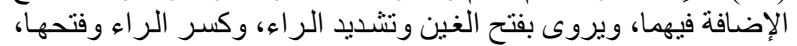

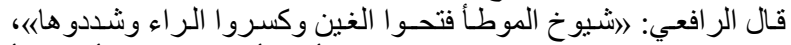

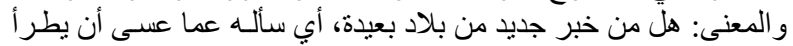

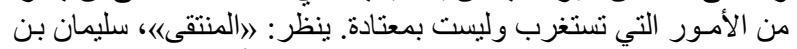

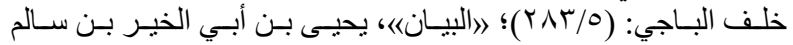

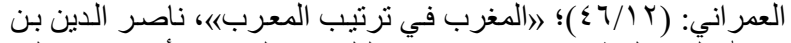

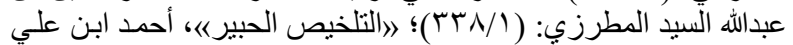

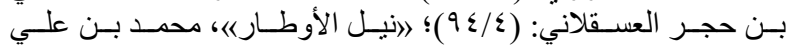

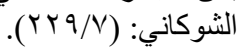

أيام قال المالكية(')، و والحنابلة(r)، وهو قول للشافعي( (َ)، رحمه الله أجمعين.

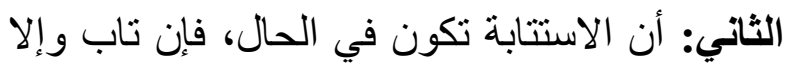

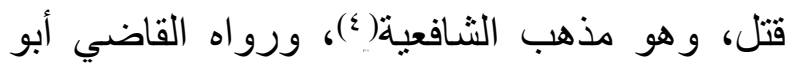
الحسن عن مالك(*)، وبه قال الحنفية فيما إذا لم

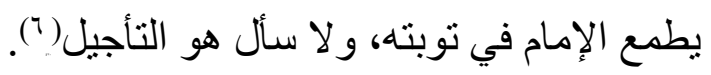

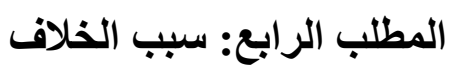
الذي يظهر لي أن السبب في اختلاف الفقهاء رحمهم الله - في المسألة، اختلافهم في وجه الدلالة

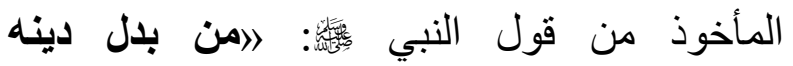

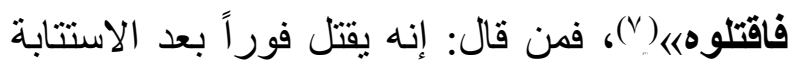

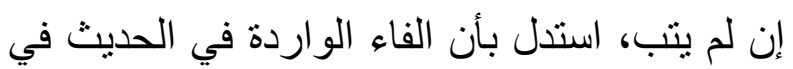

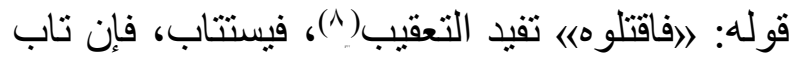
وإلا قتل ولا يمهل، ومن ذهب إلى إمهاله جعل

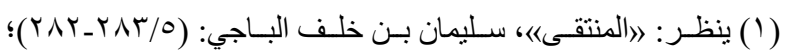

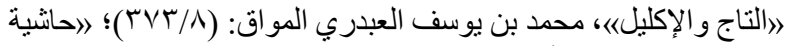

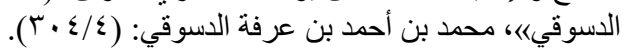

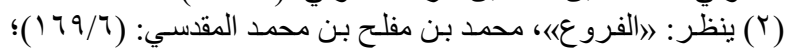

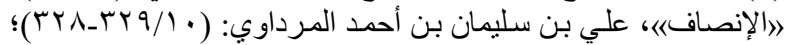

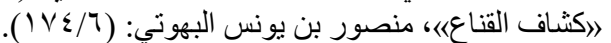

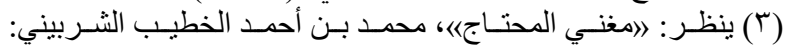

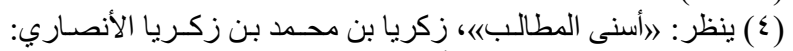

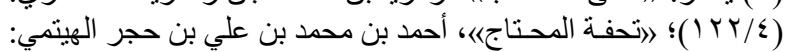

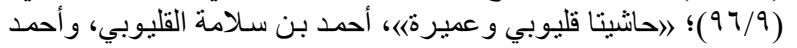

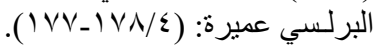

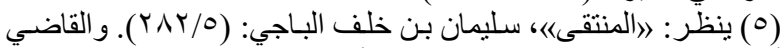

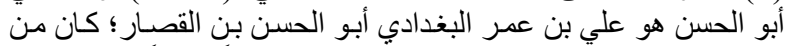

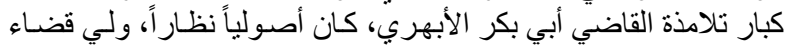

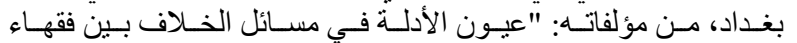

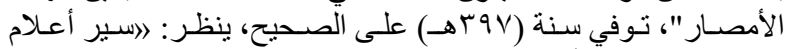

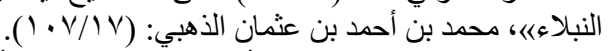

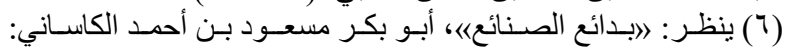

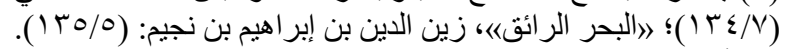
(V)

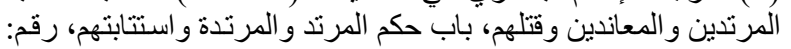

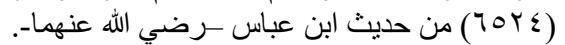

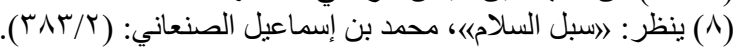


رابعاً: المعقول

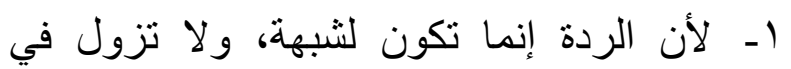
الحال، فوجب أن ينتظر فيها مدة، يرتئي فيها، وأولى ذللك ثلاثة أيام؛ للأثر الوارد فيها، وأنها مدة قريبة(V)، إذ هي أول حد الكثرة، وآخر حد القلة(^).

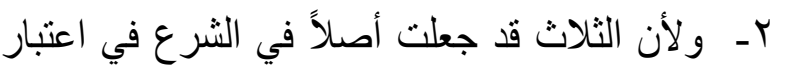
معان واختيارها، في الدصراة(9)، وفي استظهار المستحاضة و غير ذللك من المعاني (·).' و واستذل أصحاب القول الثاني لمذهبهم في أن استتابة المرتد تكون في الحال، فإن تاب و إلا قتل، بالسنة النة النقابة

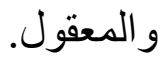

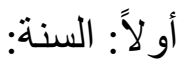

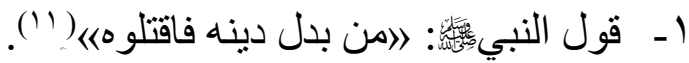
وجه الدلالة: دل ظاهر الحدث على أن المرتد يقتل

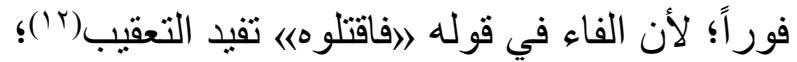

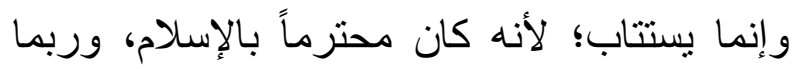

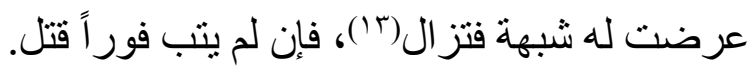

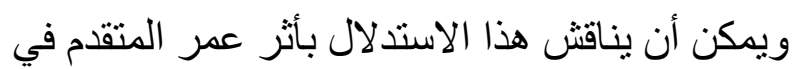

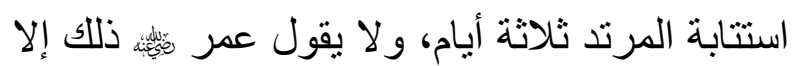

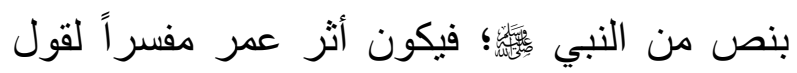

(Y) ينظر : (المغني《)، موفق الدين عبدالله بن أحمد بن قدامة: (T/9).

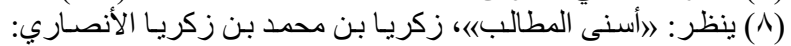

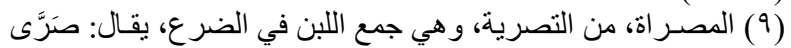

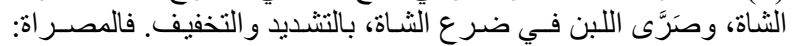

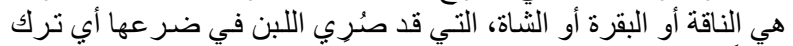

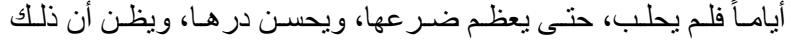

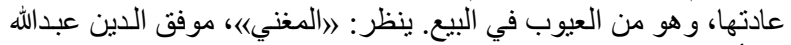

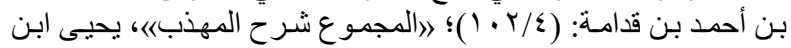

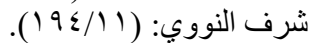

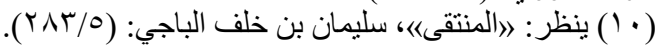

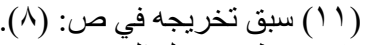

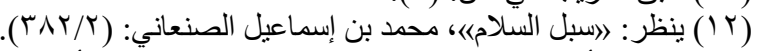

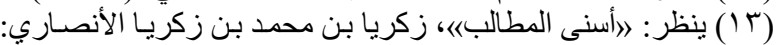

بعد إسلامه، قال فما فعلتم به؟ قال: قربناه فضربنا عنقه، فقال عمر: أفلا حبستموه ثناثاً، وأطعمتموه كل يوم رغيفاً، واستتبتموه لعله يتوب، وير اجع أمر هر

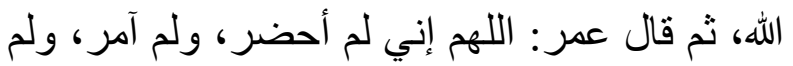

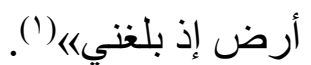
وجه الالالة: الأثر صريح في استتابة المرتد ثلاثاً،

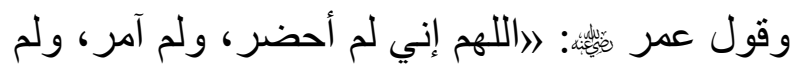
أرض إذ بلغنيه، تبرؤ من الأمر، وتصريح بخط النطأ

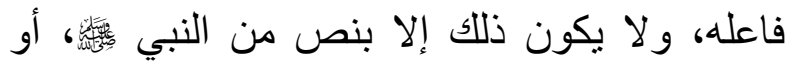

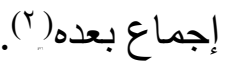
ثَالثاً: الإجماع استدل الجمهور لمذهبهم في استتابة المرتد ثثلاثة أيام

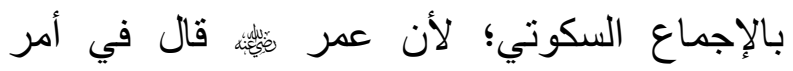
المرند: أفلا حبستموه ثلاثاً، ولم ينكر ذلك أحد من

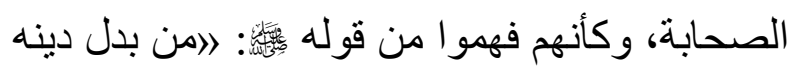

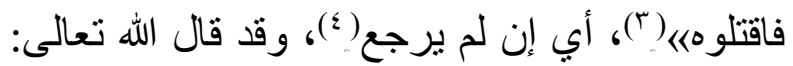

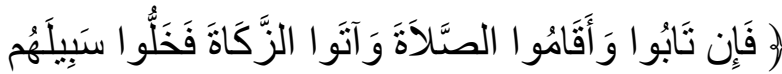

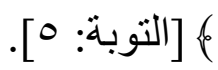

ونوقش الاستدلال بأنه لا بصح إلا بأحد وجهين:

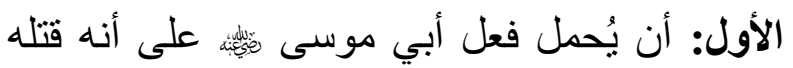
بعد الاستتابة، ولعل الناقل لم يعلم بها (0).

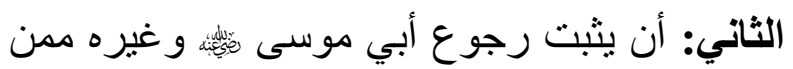

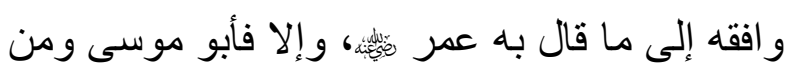
و افقه على ذللك يمنع انعقاد الإجماع على قول عمر - رضي الله عنهـ(7).

(1) (الموطأ)، مالك بن أنس الأصبحي، مع شرحه المنتقى، سليمان بن

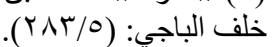

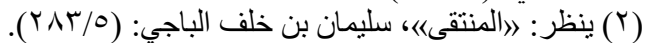

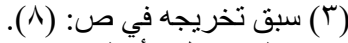

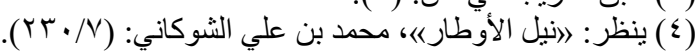

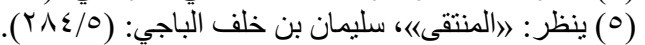

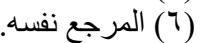


و أما حديث عائثة فقد رواه الدارقطني، وفي إسناده محمد بن عبدالملك، قال الإمام أحمد وغيره فيه: يضع الحديث. ثانياً: المعقول 1 ـ لأن المرتد مصر على كفره، أثنبه حاله بعد

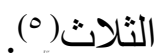
rـ ـ لأن قتل المرتد على ردنه حد، فلا يؤخَّر كسائر

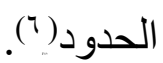
ז- لأنه استتابة، فلم يتقدر بالثلاثة، كاستتابة

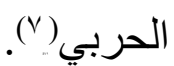
المطلب السادس: الترجيح بعد استعراض المسألة وما ورد فيها من أدلة

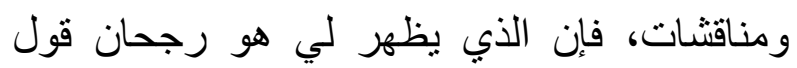

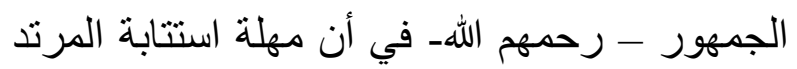

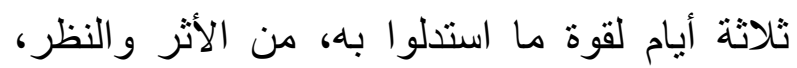

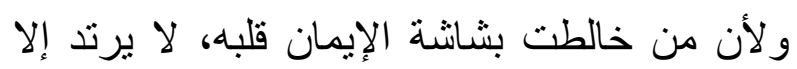

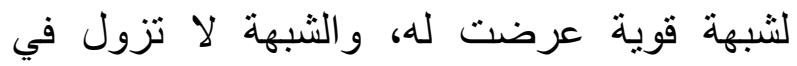

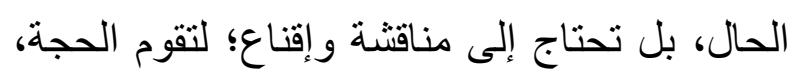

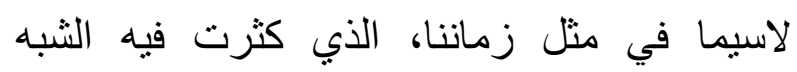

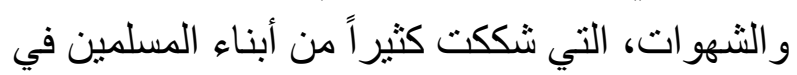

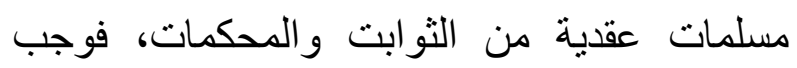

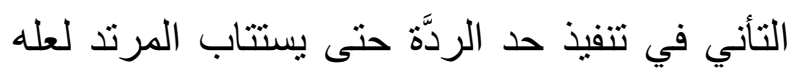
يؤوب وير اجع أمر ربه كما قال الفاروق فئسئ.

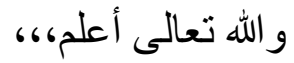

\section{المبحث الثاني \\ مهلة تارك الصلاة \\ المطلب الأول: تعريف الصلاة لغةً.}

(0) ينظر : 》المغني《)، موفق الدين عبدالله بن أحمد بن قدامة: (0/9).

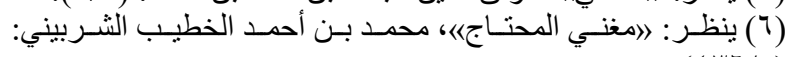

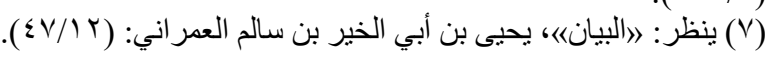

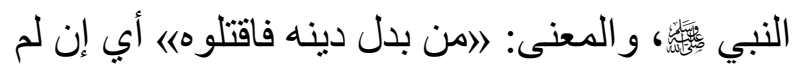

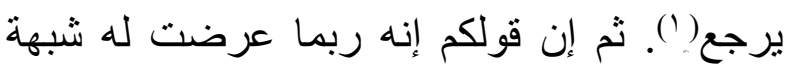

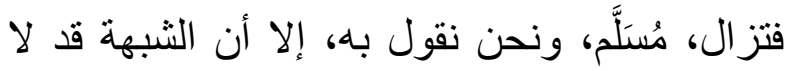

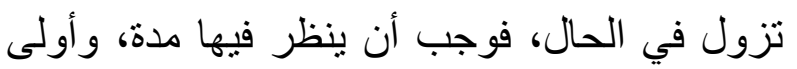
ذللك ثلاثة أيام (r)

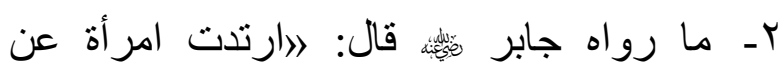

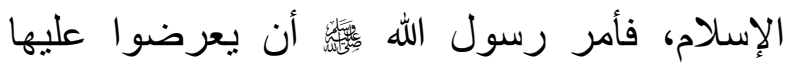

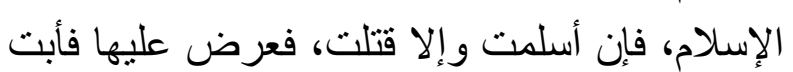

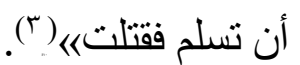

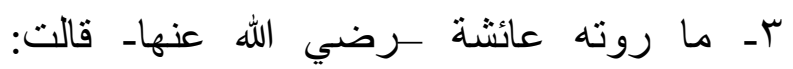

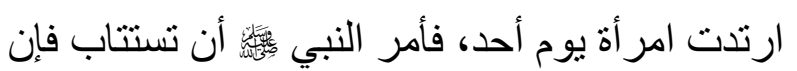

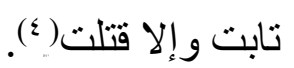
وجه الدلالة: دل الحديثان على أن المرتد يستتاب،

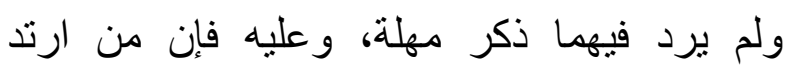

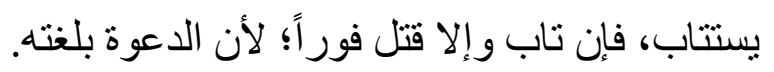

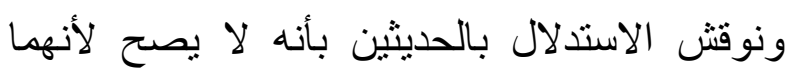

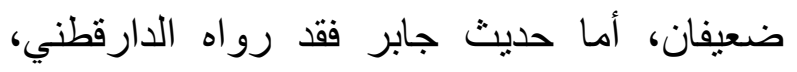
و البيهقي، من طريقين، وإسنادهما ضعيفان كما قال الحافظ ابن حجر ، و الزيلعي.

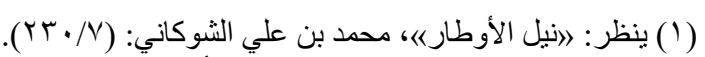

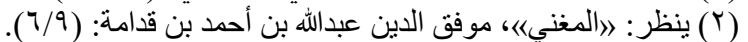

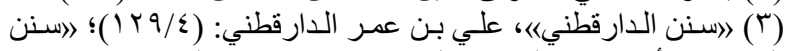

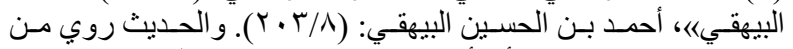

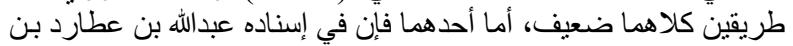

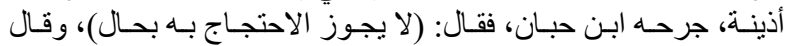

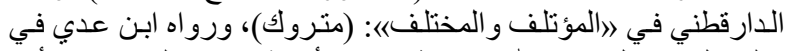

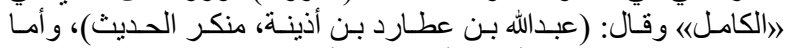

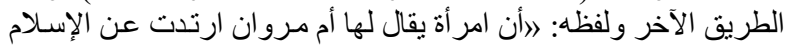

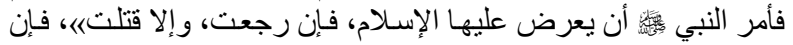

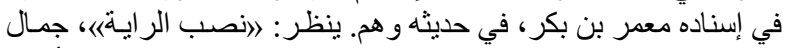

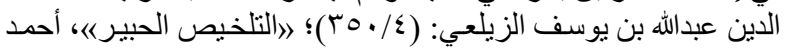

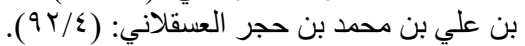

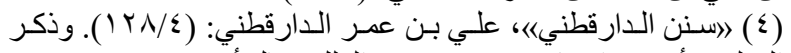

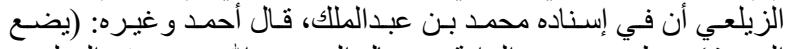

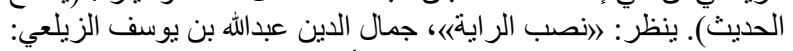

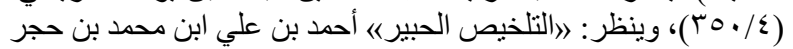
العسقلاني: (ع/ع) ( 
() أنها من الصنّا، وهو العظم الذي عليه

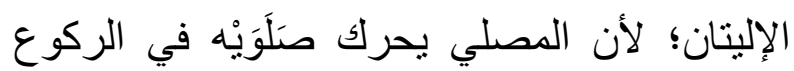

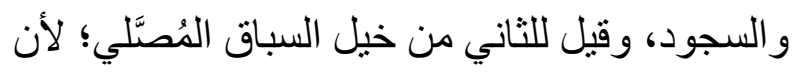

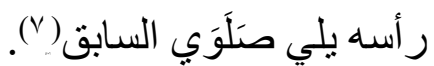

r ( ) وقيل إنما سميت هذه العبادة صلاة؛ لاشتمالها على المعنى اللغوي الذي هو الدعاء، (قال ابن رشد: هذا هو المشهور المتعارف، وقال القرافي: وعليه

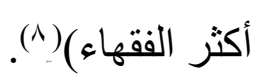

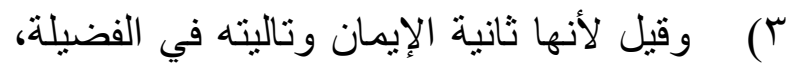

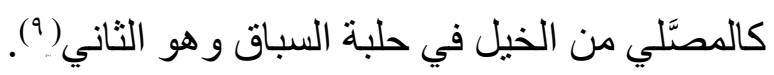

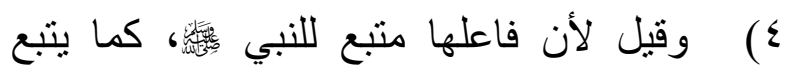
الفرس الثاني الأول(·) (1) 0) وقيل هي مأخوذة من تصلية العود بالنار؛

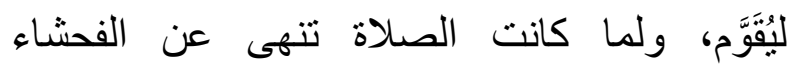
و المنكر ، كانت مقومة لفاعلها (').

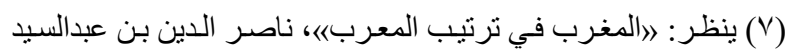

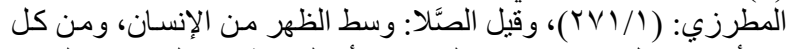

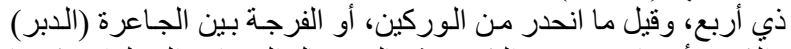

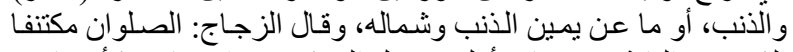

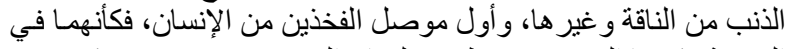

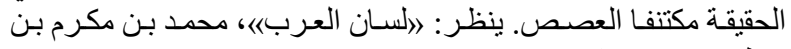
منظور : (

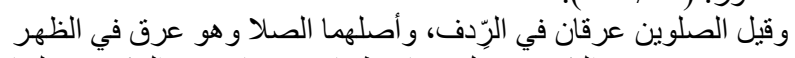

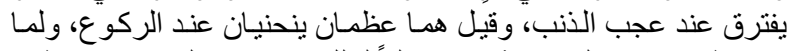

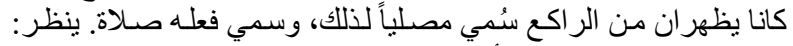

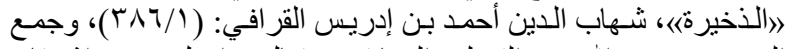

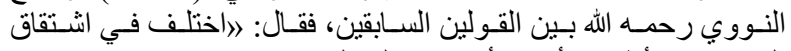

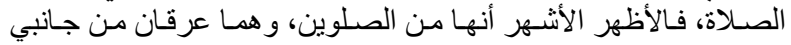

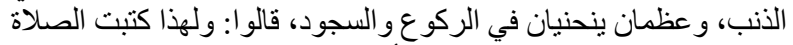

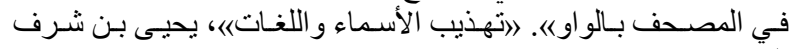

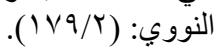

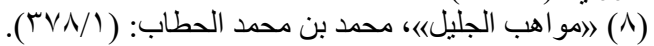

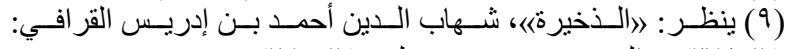

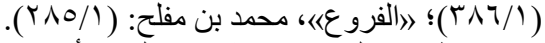

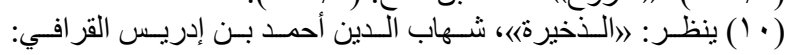

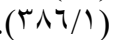

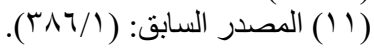

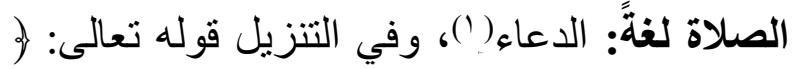

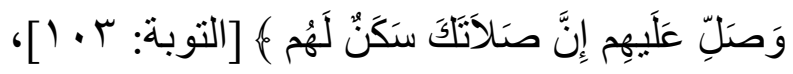

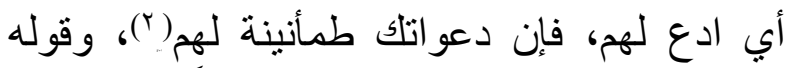

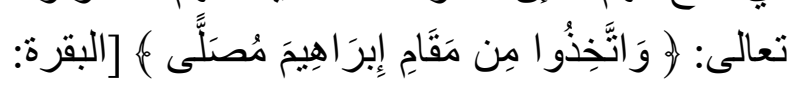

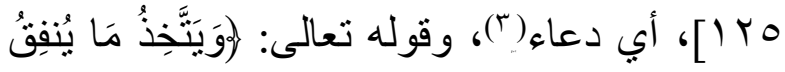

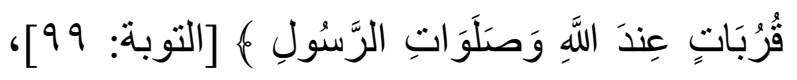

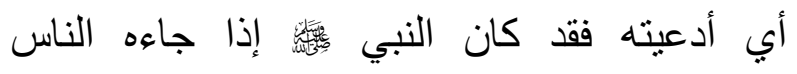

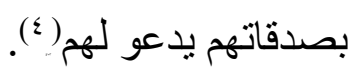

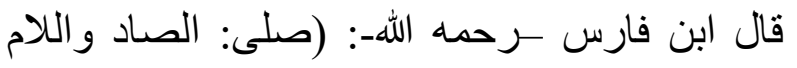
والحرف المعتل أصلان: أحدهما النار وما أثبهـها لهاديا

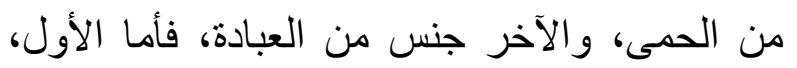

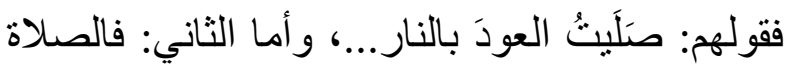

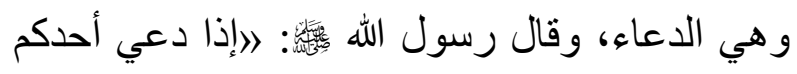

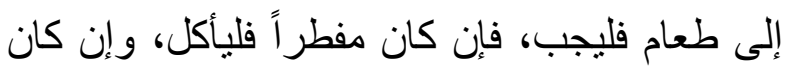

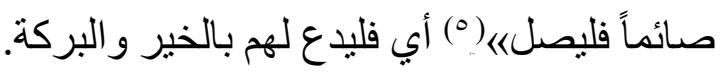

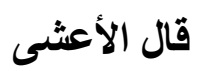

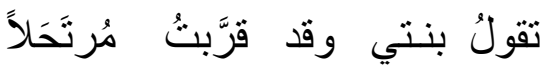

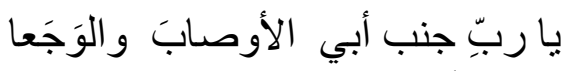

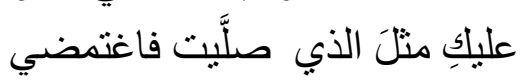

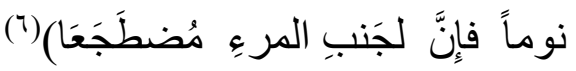

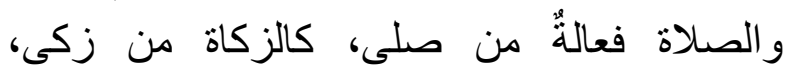
واختلف العلماء في اشتقاقها، فمما ذكروه:

(1) قال الإمام النووي ـرحمه الله-: 》اهذا قول جمـاهير العلمـاء من أهل

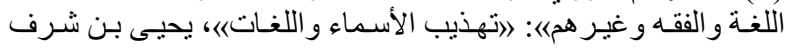

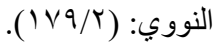

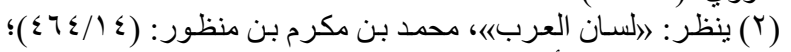

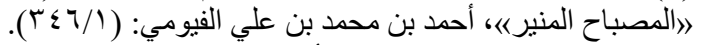

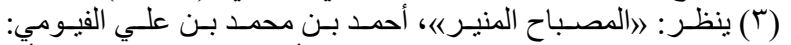

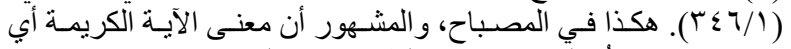

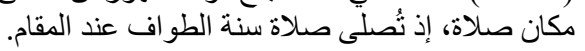

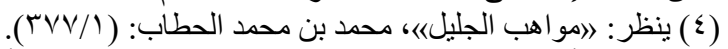

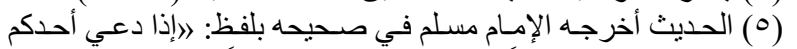

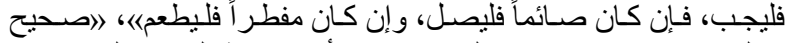

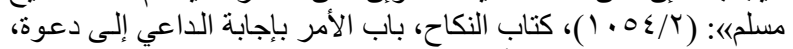

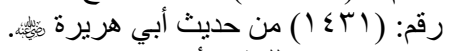

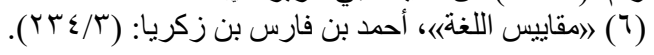


الملائكة استغفار ، ومن الآدمي تضرع ودعاءی)(^).

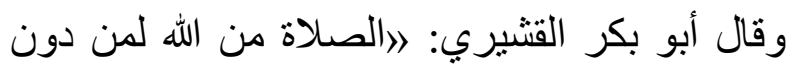

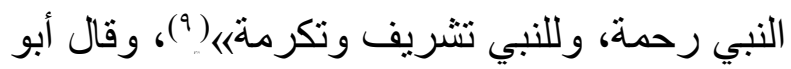
العالية: الصلاة الله عليه ثناؤه عليه

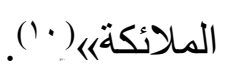

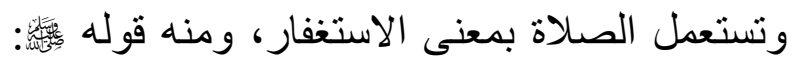
》(بعثت إلى أهل البقيع لأصلي عليهم||(")؛ فإنها فسره الحديث الآخر : اإن ربك يأمرك أن تأني أهل

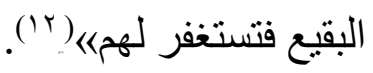

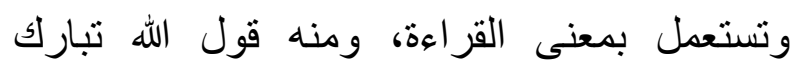

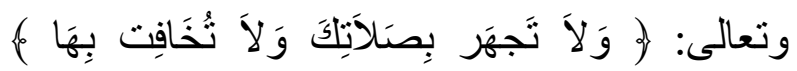

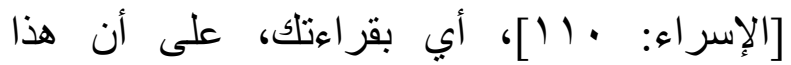

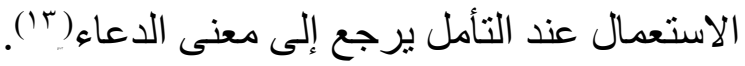
المطلب الثاني: تعريف الصلاة اصطلاحاً لا يختلف أهل العلم رحمهم الله في أن إطلاق لفظ الصلاة وغيرها من الألفاظ المشتركة في الثرع على معانيها الثرعية على سبيل الحقيقة الثرعية، بمعنى أن حملة الثرع غلب استعمالهم لتلك الألفاظ في تلك المعاني، حتى إن اللفظ لا يفهم منه عند

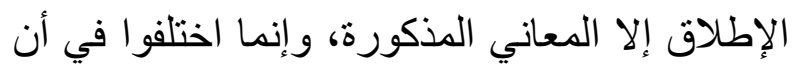
الثرع هل وضع هذه الألفاظ لهذه المعاني، أو هي

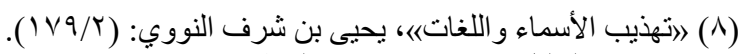

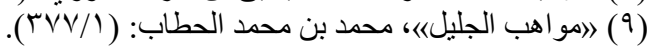

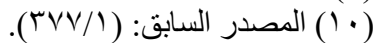

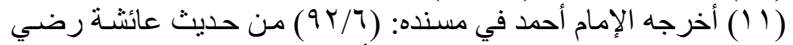

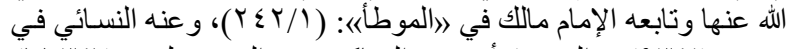

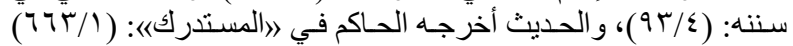

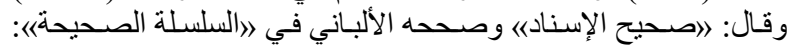

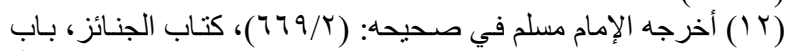

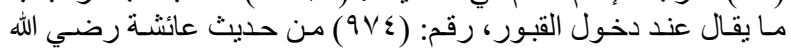
عنها. (T ( ) ينظر: (امو اهب الجليل)،، محمد بن محمد الحطاب: (YVV/I).
T) وقيل هي مأخوذة من الصلة؛ لأنها صلة بين العبد وربه، بمعنى أنه تدنيه من رحمته، وتوصله إلى كر امته وجنته ( ').

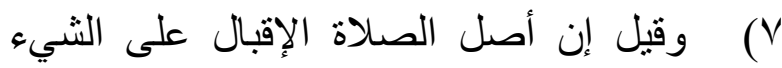
تقرباً إليه، وفي الصلاة هذا المعنى(') A) وقيل إن الأصل في الصلاة اللزوم، يقال: قد صلى واصطلى إذا لزم، ومن هذا من يصلى في الاهل

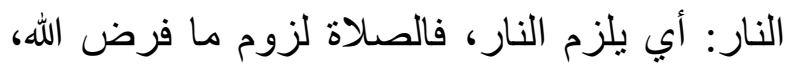
و هي من أعظم الفرض الذي أمر بلزومه (r).

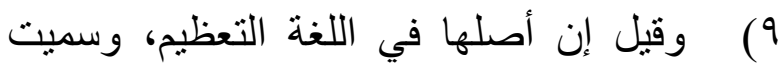
هذه العبادة صلاة؛ لما فيها من تعظيم الرب جل إل الفي و عز (\&)

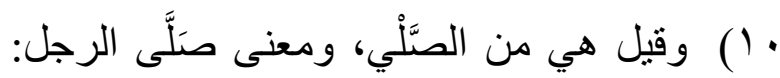
أزال عن نفسه بهذه العبادة الصَّلي الذي هو نار اللها الموقدة:(0). 1) (1) وقيل الصلاة في اللغة مشتركة بين الدعاء

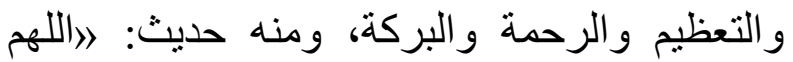

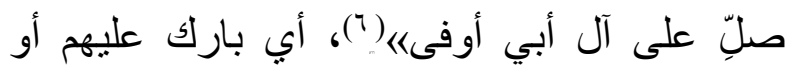
ارحمهم () و الصلاة من الله الرحمة، قال الإمام النووي ــرحمه الله: 》اقال العلماء: الصلاة من الله الرحمة، ومن الرنال

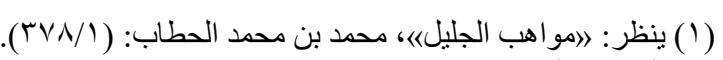

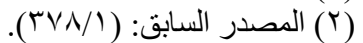

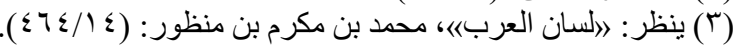

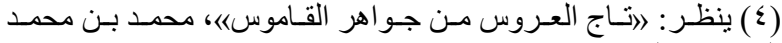

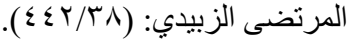

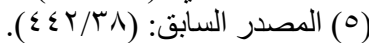

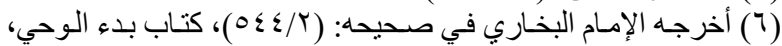

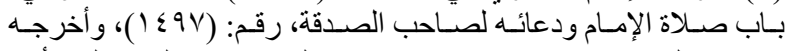

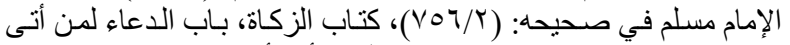

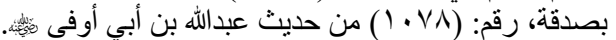

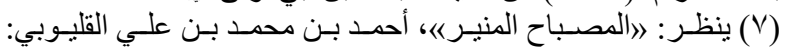
( $(\Gamma \leq T / 1)$ 
قيود ز ائدة حتى تصير شر عية، وهو مذهب القاضي

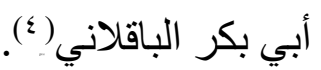

و الذي يظهر لي وأرجحه هو القول الثاني، ولذلك لبك سميت الصلاة صلاة، لاشتمالها على المعنى اللغوي الذي هو الدعاء. - اءه الصلاة اصطلاحاً: عرفها الحنفية بقولهم: اأركان مخصوصة وأذكار معلومة بشر ائط محصورة في

$$
\text { أوقات مقدرة) (0). }
$$

وقال المالكية: 》دعاء مخصوص في أوقات محدودة

$$
\text { تقترن به أفعال مشرو عةة) (ج). }
$$

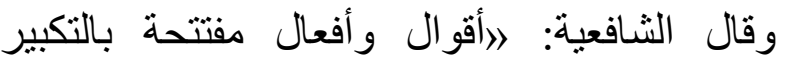

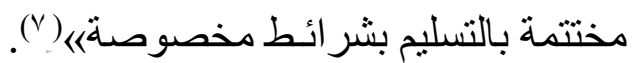

وبمثل تعريف الثافعية للصلاة عرفها الحنابلة(^). المطلب الثالث: تحرير محل التزاع في مهلة تارك

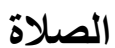

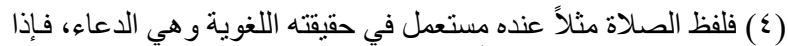

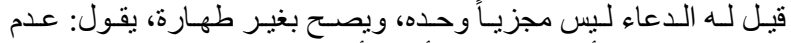

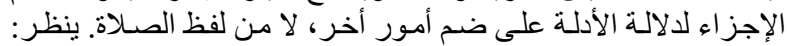

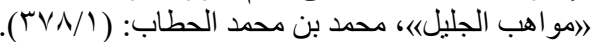

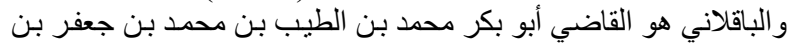

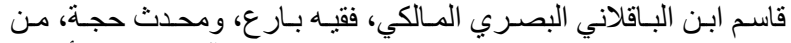

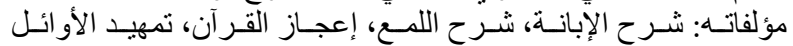

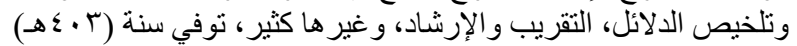

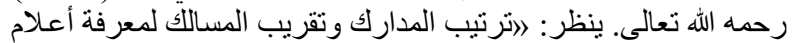

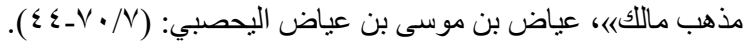

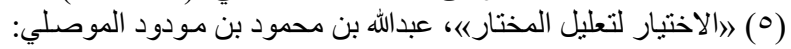

(7) 》الآلمدمات الممهداتي/، محمد بن أحمد بن أحمد بن رشد (الجد):

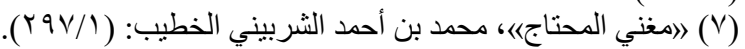

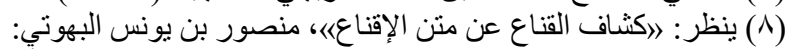

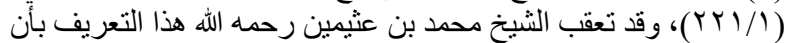

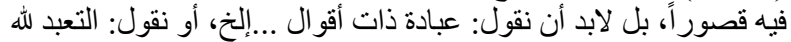

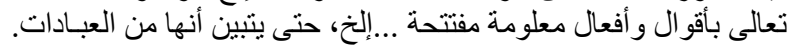

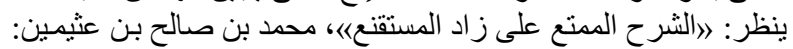

مستعملة فيها على سبيل المجاز، أو هي مستعملة في معانيها اللغوية على ثلاثة أقو ال كالتالي (')

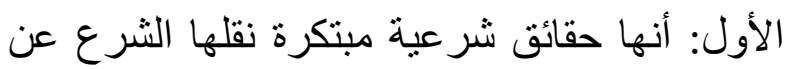

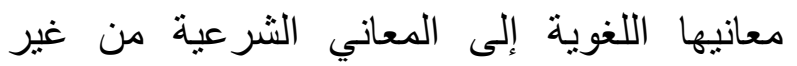

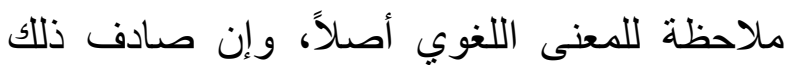

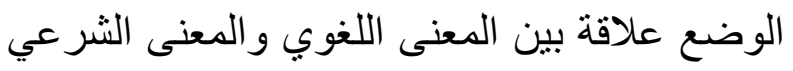

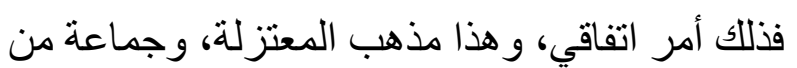
الفقهاء. ونوقش هذا القول بأنه مستبعد؛ لأنه يؤدي إلى أن تكون العرب خوطبت بغير لغتها. الثاني: أنها مستعملة في المعاني المذكورة على لفئل سبيل المجاز اللغوي؛ لمناسبة بين المعاني اللغوية،

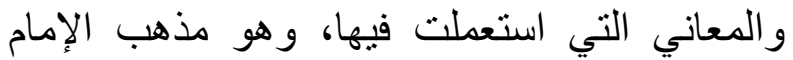

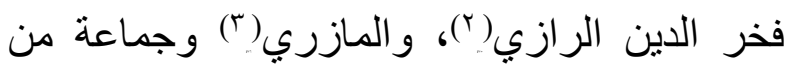
الفقهاء، إذن هي مجاز ات لغوية وحقائق شرعية.

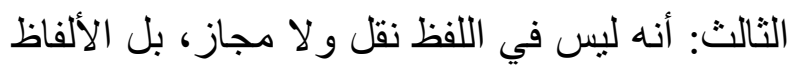

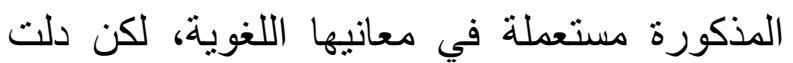

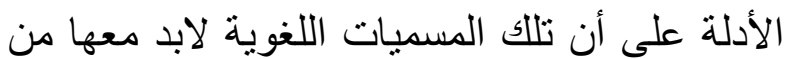

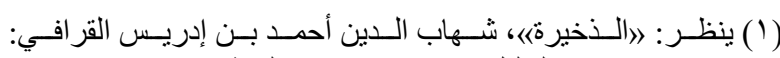

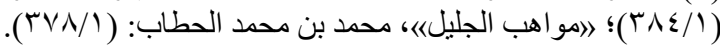

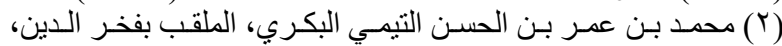

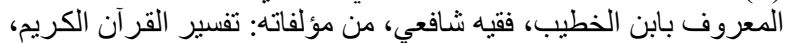

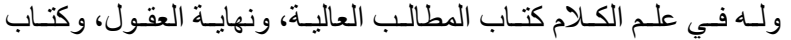

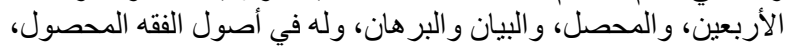

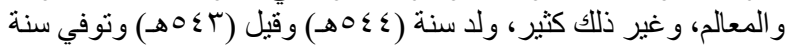

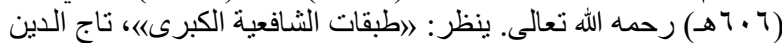

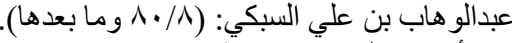

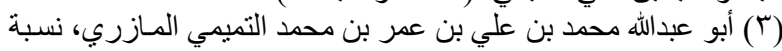

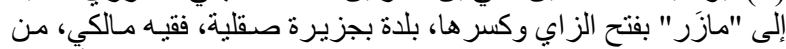

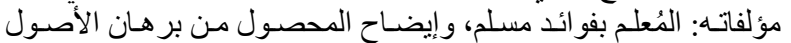

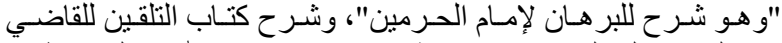

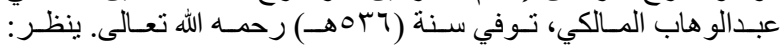

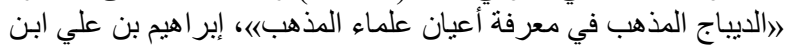

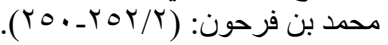




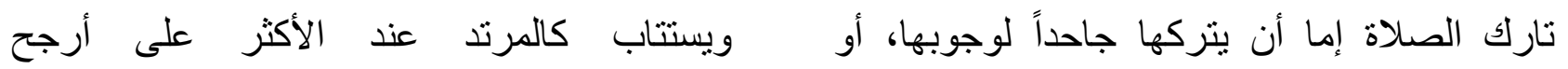

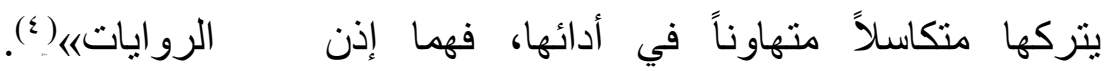
وجاء في 》أسنى المطالب) قوله في باب تارك

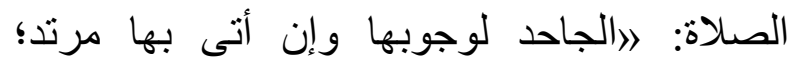
لإنكاره ما هو معلوم من الدين بالضرورة... إلا جاهل نفى ذلك لقرب عهده بالإسلام، أو نحوه ممن هون

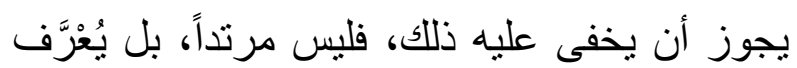

الوجوب، فإن أصر على الجحد صسار مرتداًي(). وقال ابن مفلح: اوون جحد وجوبها كفر إذا كان

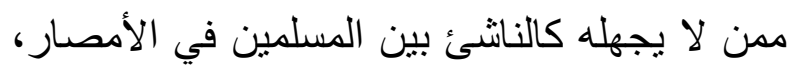
زاد ابن تميم: و إن فعلها؛ لأنه لا يجدها إلا تكذيباً لله

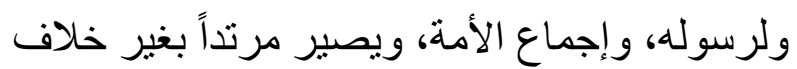

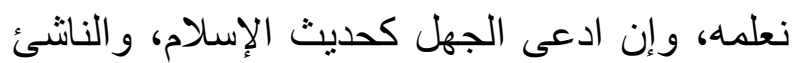
ببادية، عُرِّف وجوبها، ولم ولم بحكم بكفره؛ لأنه

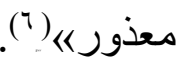

فالحاصل إذن أن من ترك الصداة جحداً لوجوبها يصير مرتداً بذلك، فيمهل مهلة المرتد كما سبق ترك ذكره في مسألة مهلة استتابة المرتد. المسألة الثانية: مهلة تارك الصلاة كسلاً وتهاوناً

اتفق أهل العلم -رحمهم الله- على أن تارك الصهلاة جحداً لها، إذا كان من أهل الوجوب، ولم يكن له له

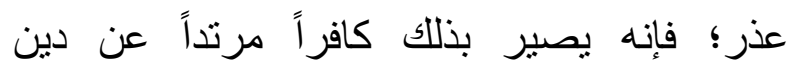
الإسلام، فيستتاب فإن لم يتب قتل لردته كما تقدم، ثم

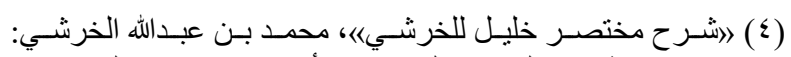

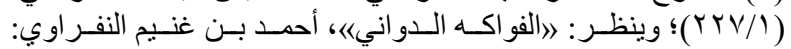
( (1 $7 \leqslant / 1)$

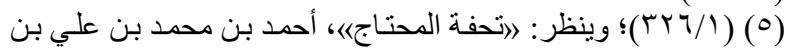

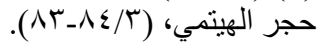

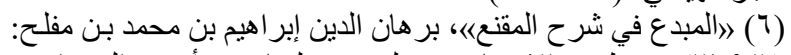

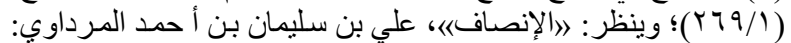

المسألة الأولى: مهلة تارك الصلاة جدداً لوجوبها.

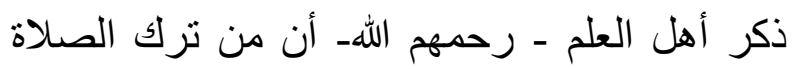

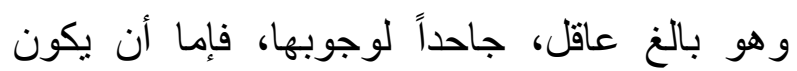
جاهلاً بهذا الحكم، وهو ممن قد يجهل ذلك كحديث العهد بالإسلام، أو من نشأ ببادية، ونحو ها، فمثل هذا هُن يُعرَّف وجوبها، ويعلم ذللك ولا يحكم بكفره؛ لأنه معذور. وإما أن يكون ممن لا يجهل ذللك، كمن نشأ في

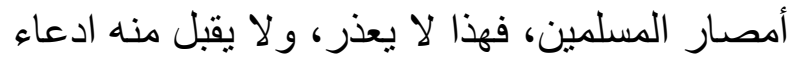
الجهل، ويحكم بكفره؛ لأن أدلة الوجوب ظاهرة في

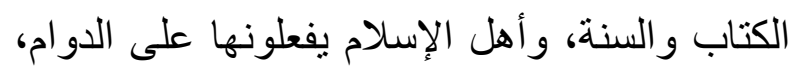
فلا يخفى وجوبها على من هذه حاله، فلا يجحدها إلا تكذيباً لله تعالى، ولرسوله، ولإجماع الأمة، ورذا هذها يصير مرتداً عن الإسلام وحكمه حكم سائر المرتدين( ')، كما في المسألة السابقة(r) في الاستتابة

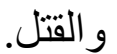
جاء في لادرر الحكام شرح غرر الأحكام|()": 》اومنكر ها أي منكر الصلاة المكتوبة، بمعنى منكر

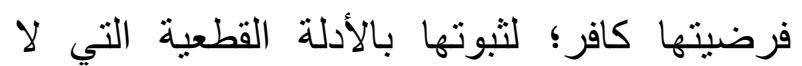
احتمال فيها، فحكمه حكم المرتدها.

وقال الخرشي: اوالتارك الجاحد لمشروعية

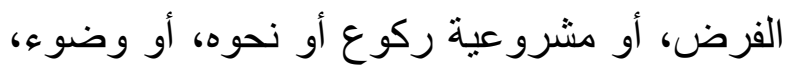
وليس حديث عهد بالإسلام كافر اتفاقاً، بل إجماعاً،

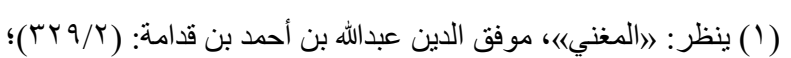

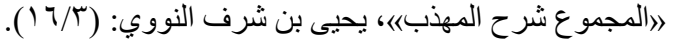

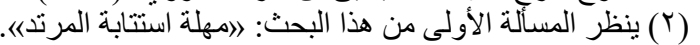

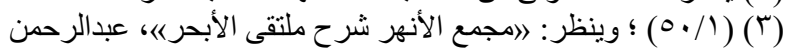
بن محمد شيخي زاده: (1) ( 
جاء في 》امغني المحتاج||(·) قوله عن تارك الصلاة تهاوناً: \...وتوبته على الفور؛ لأن الإمهال

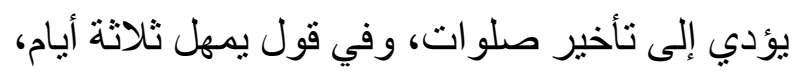

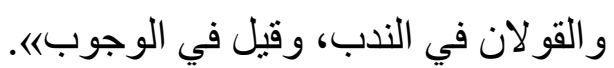

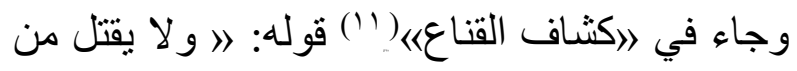

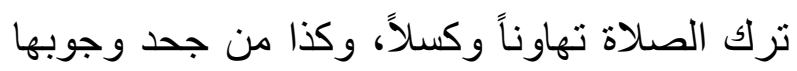
حتى يستتاب ثلاثة أيام كمرنداء. وقال المواق عن تارك الصلاة: لا ويستتاب، وهل وهل

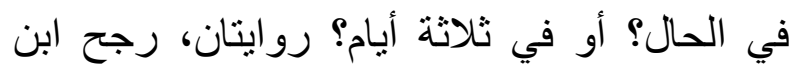

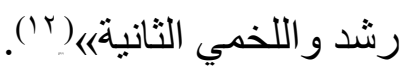

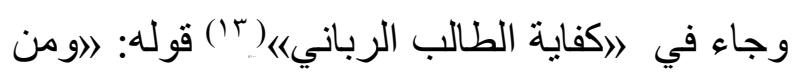

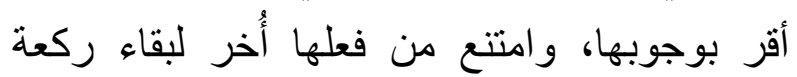
بسجدتيها من الضروري، فإن لم يفعل قتل حداًا).

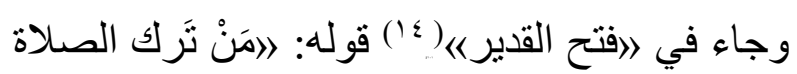

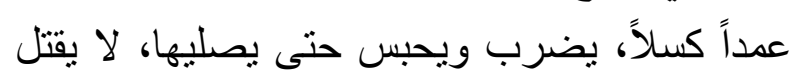

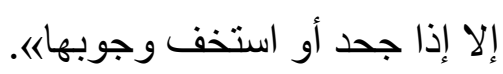

\section{المطلب الرابع: سبب الخلاف في المسألة}

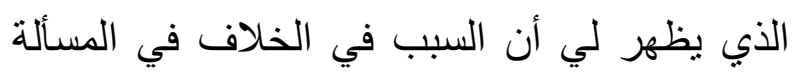

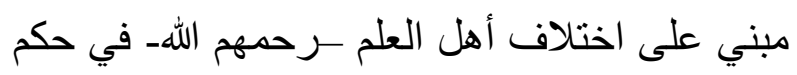
تارك الصلاة تهاوناً، فمن جعله منهم بذللك مرتداً

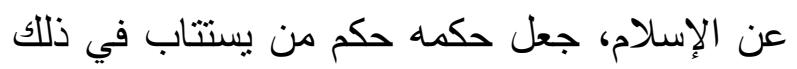

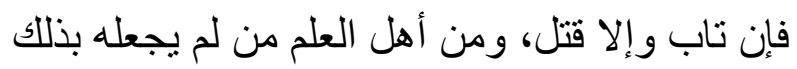

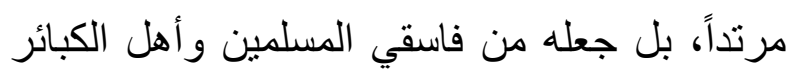

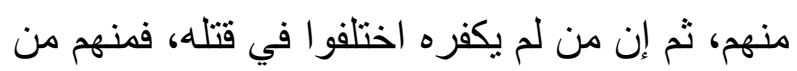

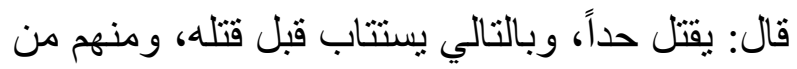

( ( ( T T T/ $)(1 \cdot)$

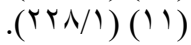

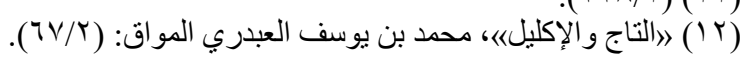

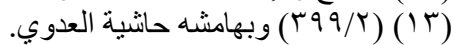

.$(\leq 9 \vee / 1)(1 \leq)$
اختلفو ا في مهلة من تركها كسلاً وتهاوناً مع إقراره

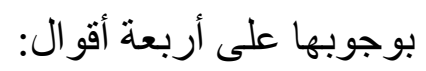
القول الأول: أنه يستتاب في الحال فإن تاب و وإلا قتل حداً، وهو مذهب الثافعية، واستتابته مندوب إليهاب اليها

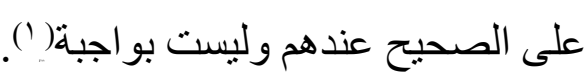

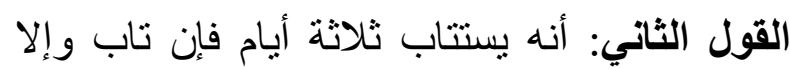

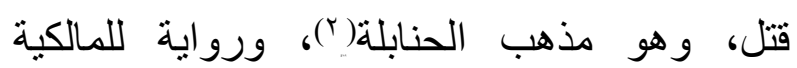

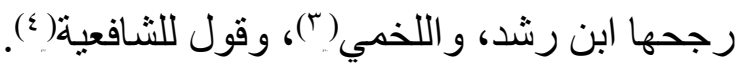

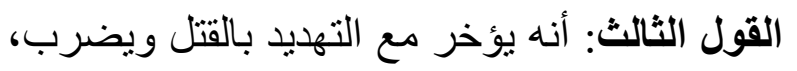

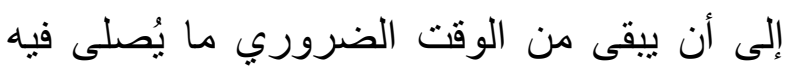

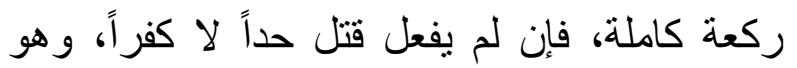

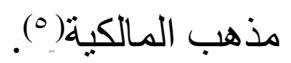
القول الرابع: يحبس تارك الصلاة تهاوناً ولا يقتل،

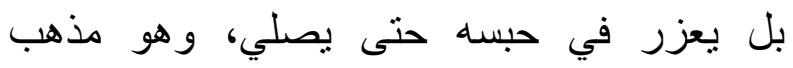

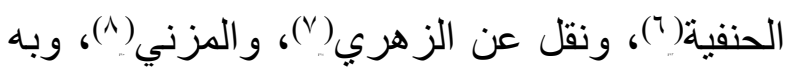
قال ابن حزم) (9).

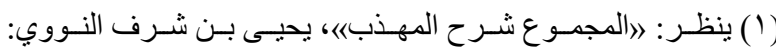

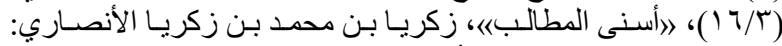

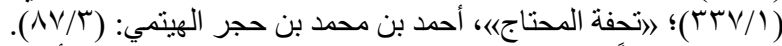

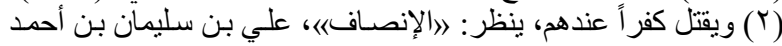

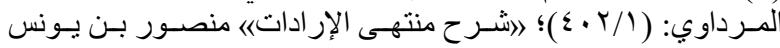

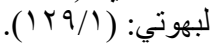

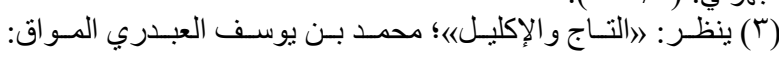
. ( $(\mathrm{V} / \mathrm{T})$

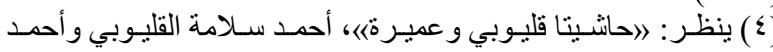

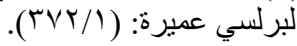

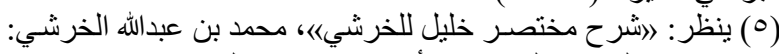

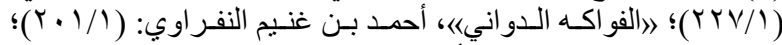

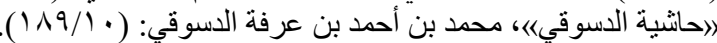

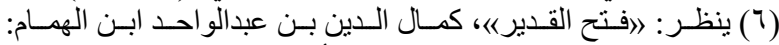

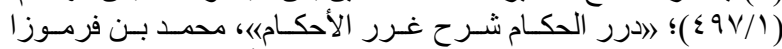

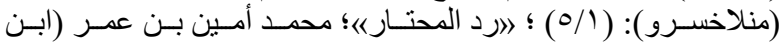

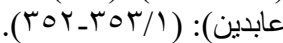

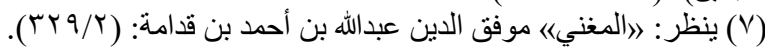

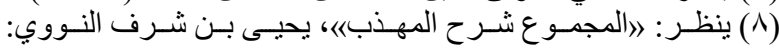

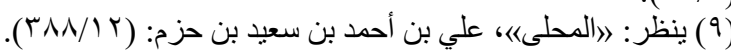




\section{المطلب الخامس: الأدلة.}

ليس الكلام في المسألة متعلقاً بحكم تارك الصالهاة هل

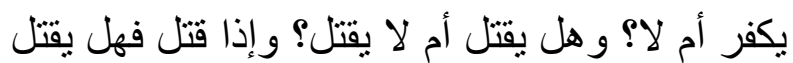

$$
\text { كفراً أم حداً؟ }
$$

بل الكلام ينحصر في المهلة التي تعطى لتارك الصلاة تهاوناً عند من يقول بقتله سواء كان فتله كفراً، أو حداً، أما من لم ير قتله فلا ترد المسألة عندهم أصلاً؛ لأنهم يقولون بحبسه وتعزيره.

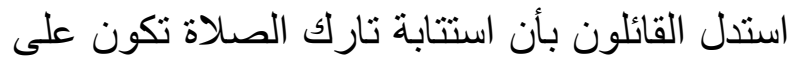
الفور فإن تاب و إلا قتل بالمعقول، ومن ذللك:

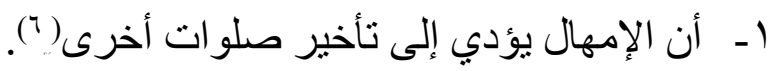
r- أن قتل تارك الصلاة حد، فلا يؤخر كسائر

$$
\text { الحدود) (v) }
$$

r- لأنه استتابة فلم يتقدر بالثلاث، كاستتابة

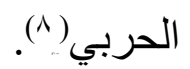

ويمكن أن يستدل للقائلين بأن تارك الصلاة تهاوناً يستتاب ثلاثة أيام، فإن تاب وإلا قتل بالقياس على بلى

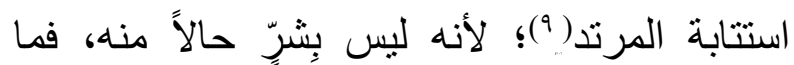

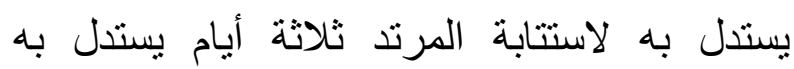

$$
\text { هi) (1) }
$$

و استدل القائلون بأنه يؤخر إلى أن يبقى من الوقت

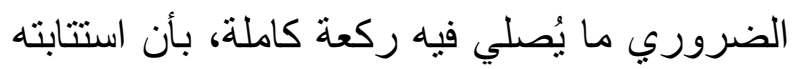

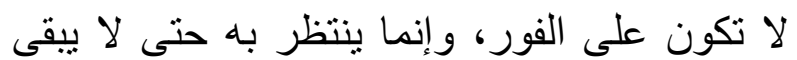

ونفيه عن المتلبس بالمعصية على إرادة نفي كماله، رقم: (OV) من حديث

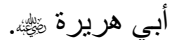
(0) (ابداية المجتهد ونهاية المقتصدي)، محمد بن أحمد بن محمد بن أحمد

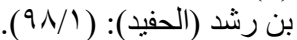

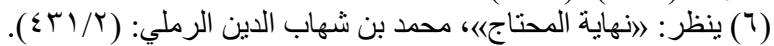

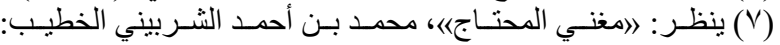
. $(\leqslant r \% / 0)$

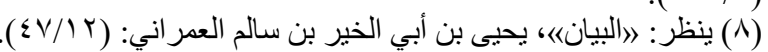

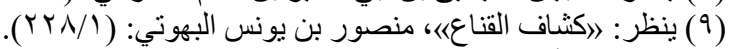

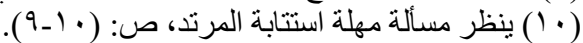

قال لا يقتل بل يحبس ويعزر؛ ولهذا لا ترد المهلة في حقه، والسبب في ذلك الاختلاف اختلاف الآثار. قال ابن رشد عن سبب التناف في العلماء فئلاء في حكم تارك الصلاة تهاوناً:

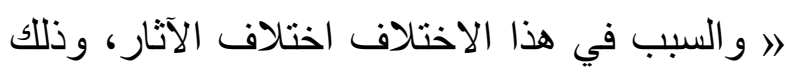
أنه ثبت عنه عليه الصلاة والسلام أنه قال: إلا يحل

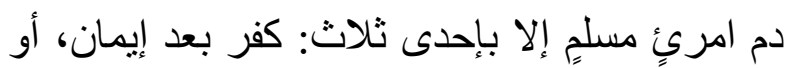

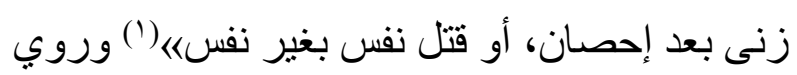
عنه عليه الصلاة والسلام من حديث بريدة قال:

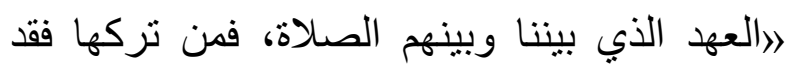

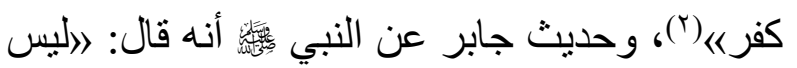

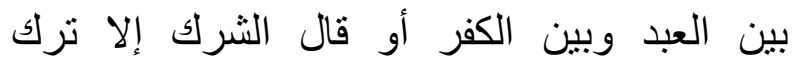
الصلاة)|(") فمن فهم من الكفر هاهنا الكفر الحقيقي جعل هذا الحديث كأنه تفسير لقوله عليه الصلاة

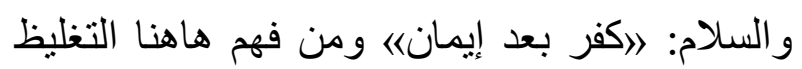

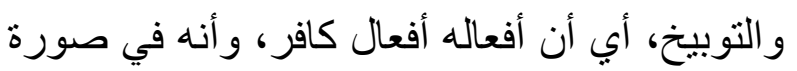
كافر، كما قال: اولا يزني الز الزاني حين بزني وهو

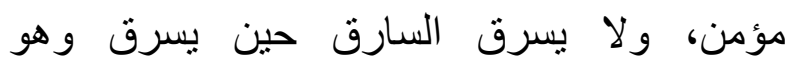

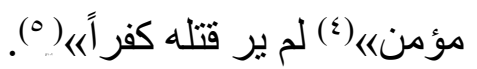

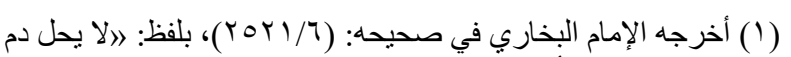

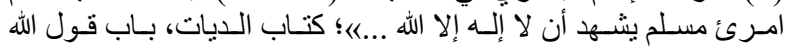

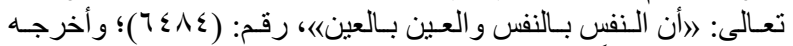

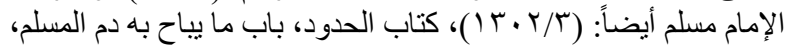

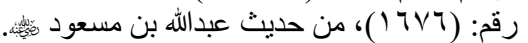

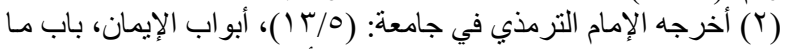

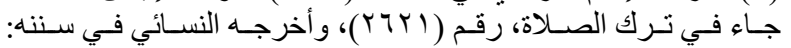

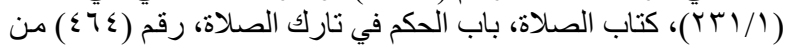

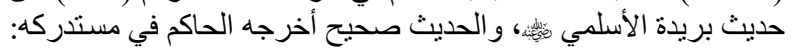

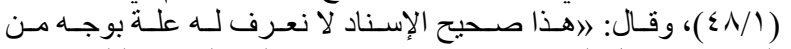

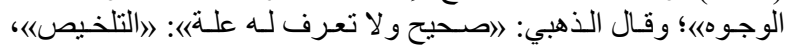

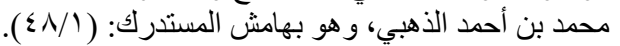

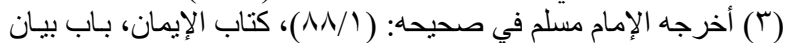

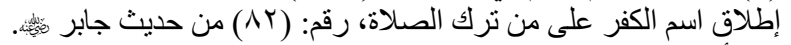

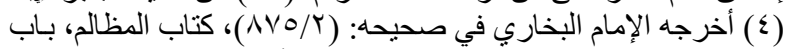

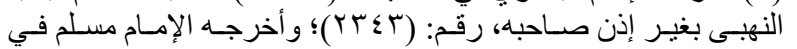

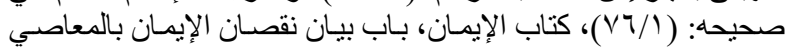


عذبه/) مانع من قول من قال: إنه لا يغفر لله، ومانع

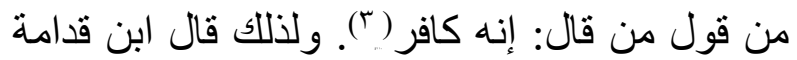
رحمه الله: \... لا نعلم في عصر من الأعصار أحداً

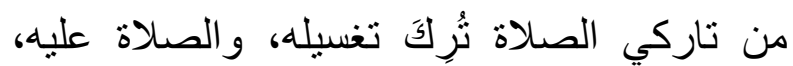
ودفنه في مقابر المسلمين، ورلا مُنِع ورثته مير اثنه،

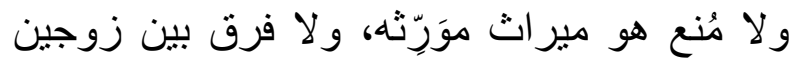

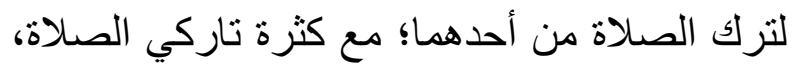

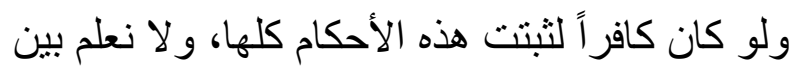
المسلمين خلافاً في أن تارك الصلاة يجب هله عليه قضاؤها، ولو كان مرتداً لم يجب عليه قضاء صلاء صلاة

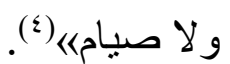

فالذي يترجح عندي في هذه المسألة أنه إن كان لا

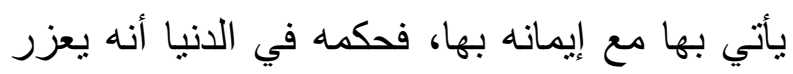

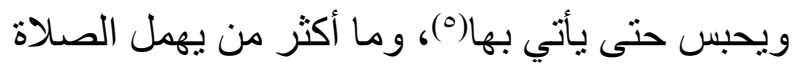
تهاوناً في أيامنا هذه دهراً من عمره، لاسيما في الاني

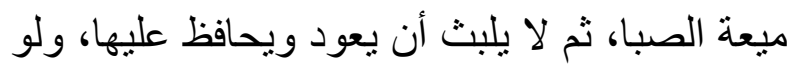

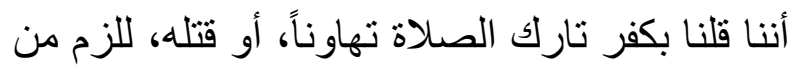
ذللك قتل كثير من شباب هذا الزمان، ومن له صلة بتربية الثباب ومعرفة الو اقع يعلم حقيقة ما أقول. و الله تعالى أعلم،، كلبه

\section{مهلة مانع الزكاة المبحث الثالث المطلب الأول: تعريف الزكاة لغةً:}

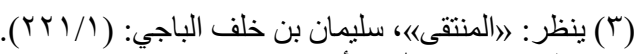

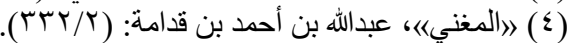

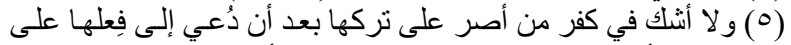

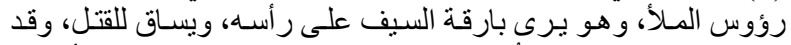

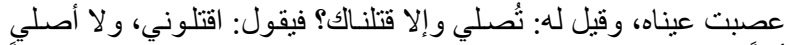

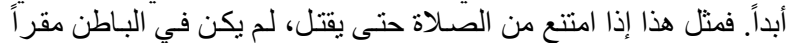

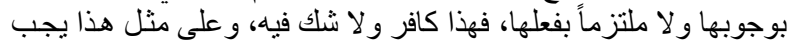

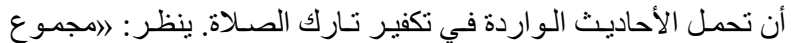

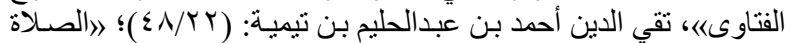

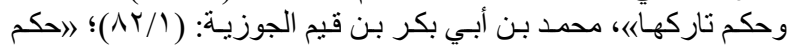

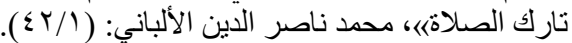

من الوقت الضروري إلا ما يُصلى فيه ركعة احتباطاً وصوناً للاماء) (1) و أما من ذهب من أهل العلم إلى حبس تارك الصلاة تهاوناً وتعزيره حتى يصلي؛ فإنهم لا يرون عليه استتابة؛ لأنهم لا يرون قتله أصلاً لا كفر أ ولا حداً، لأل فليست المهلة واردة على قولهم لتارك الصلاة. المطلب السادس: الترجيح.

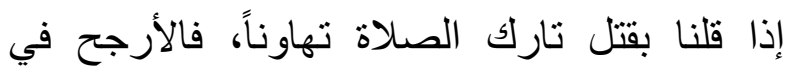

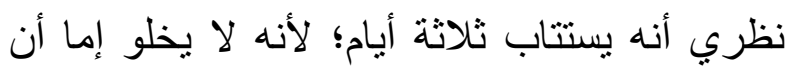
يكفر بتركه الصلاة، فيقتل كفراً، أو لا يكفر فيقتل

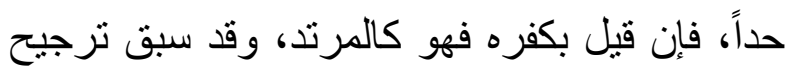

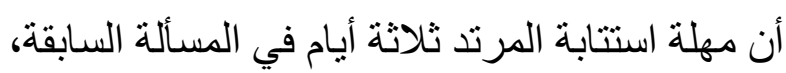

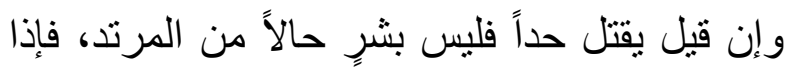

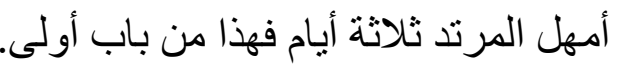

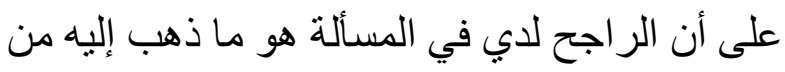

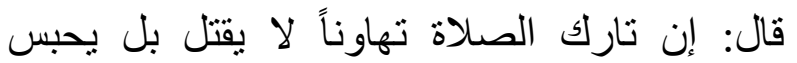

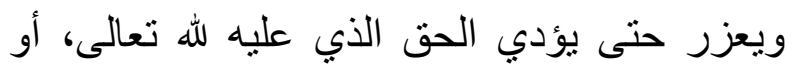

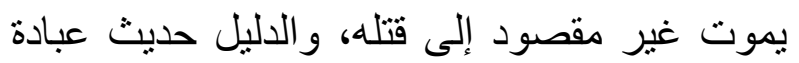

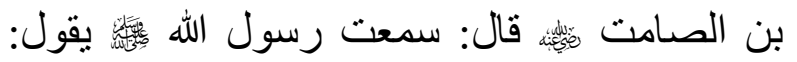
״خمس صلوات افترضهن الله تعالى، من أحسن

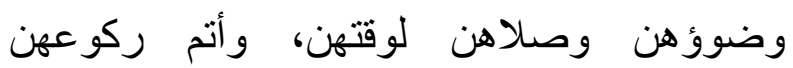

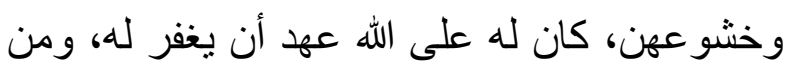

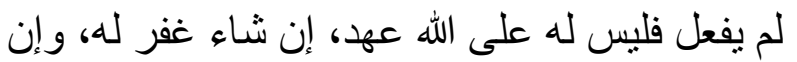

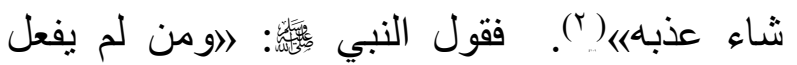
فليس له على الله عهد، إن شاء غفر لله، وإن شاء لهاء

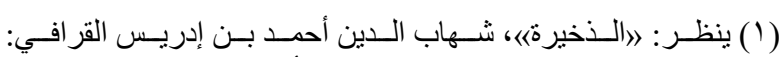

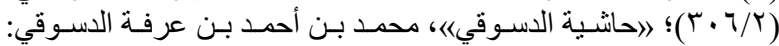
( $(19 \cdot / 1)$

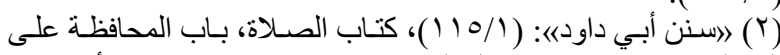

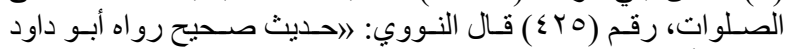

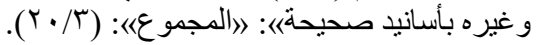


والأخروية، يقال: زكا الزرع بزكو إذا حصل منه

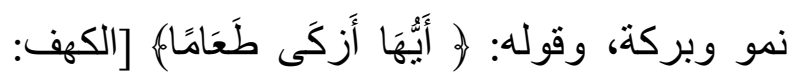
19] إثارة إلى ما يكون حلالاً لا يستوخم عقباهاه

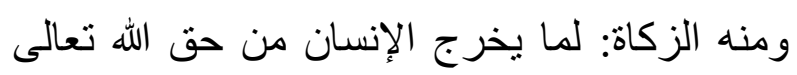

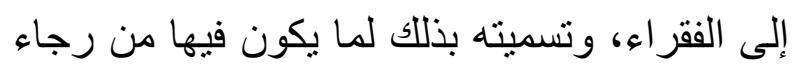

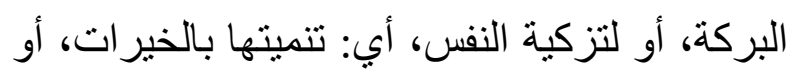

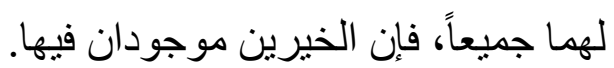

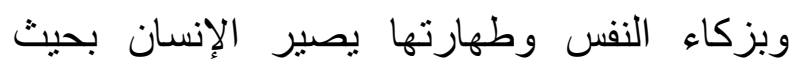
بستحق في الدنيا الأوصاف المحمودة، وفي الآخرة الأجر والمثوبة، وهو أن يتحرى الإنسان ما فيه تطهيره، وذلك ينسب تارة إلى العبد بكونه مكتسباً الإنسا

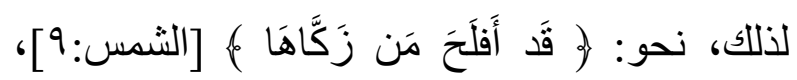
وتارة ينسب إلى الله، لكونه فاعلاً لذلك في الحقيقة الكّاء

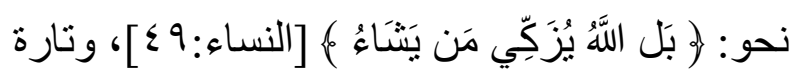
إلى النبي ئس

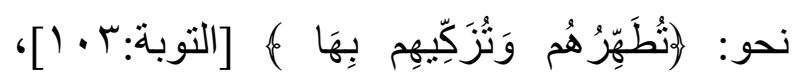

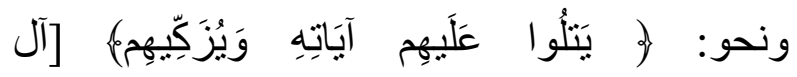
عمران:؟ 17]، وتارة إلى العبادة التي هي آلة في

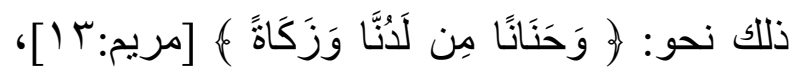

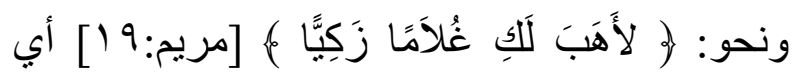
مزكى بالخلقة. - مزي.

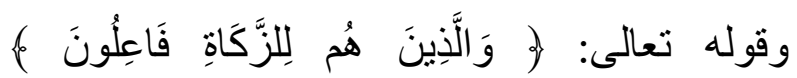

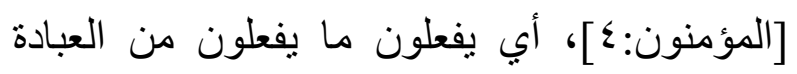

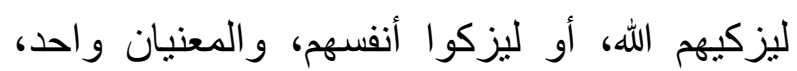

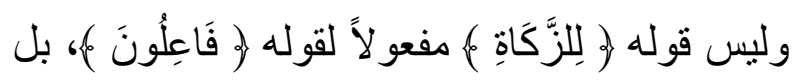
اللام فيه للعلة و القصد.

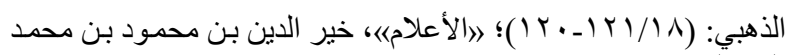

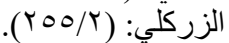

الزكاة لغة: لفظة مشتركة بين النماء و الطهارة( ').

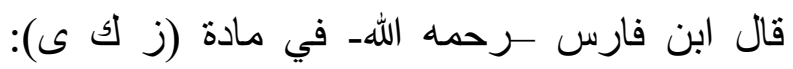

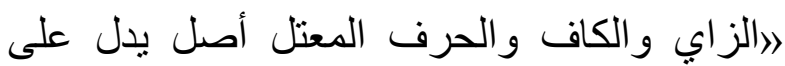
نماء وزيادة، ويقال: الطهارة زكاة المال... سميت

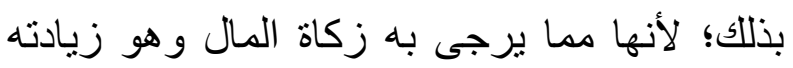

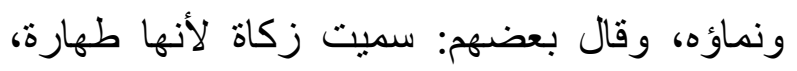

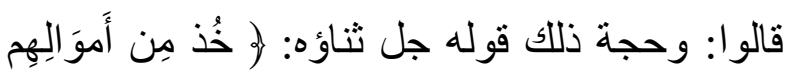

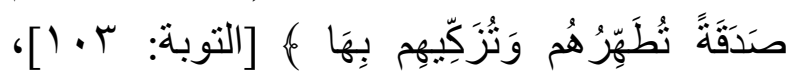

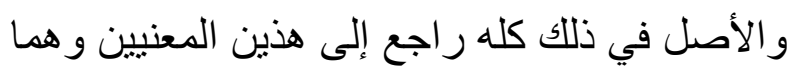

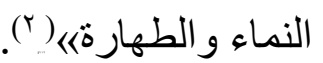

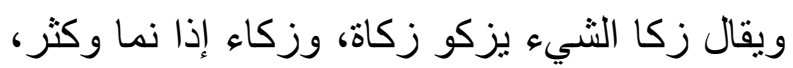

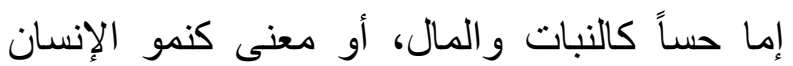

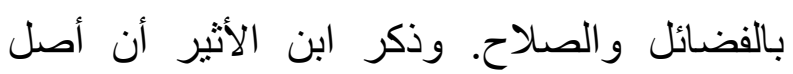

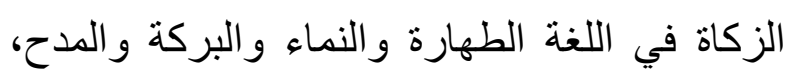

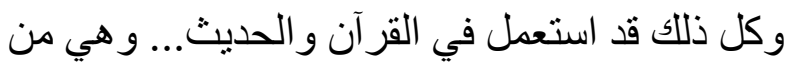

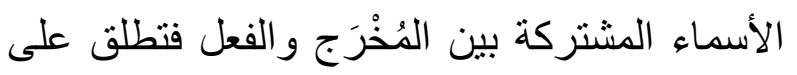

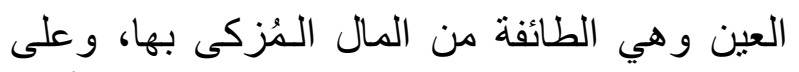

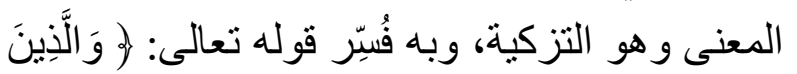

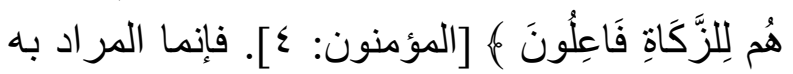

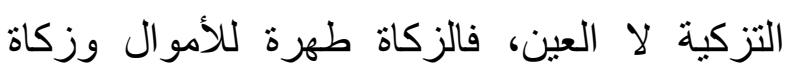
الفطر طهرة للأبدان(").

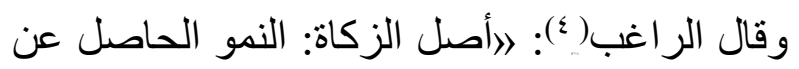
بركة الله تعالى، ويعتبر ذلك بالأمور الدنيو الدية الداهية

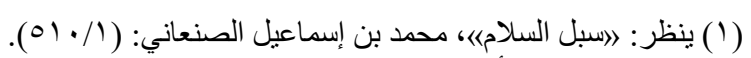

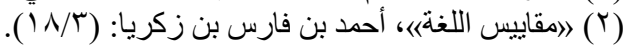

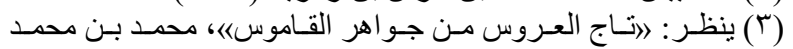

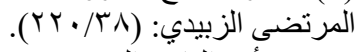

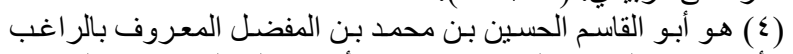

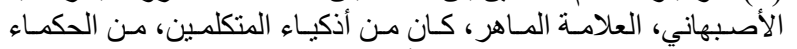

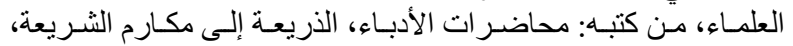

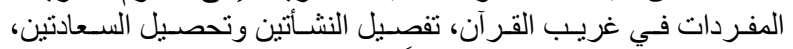

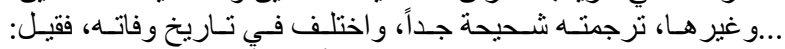

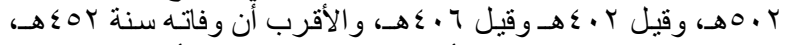
رحمه الله تعالى. ينظر : (اسير أعلام النبلاء)، محمد بن أحمد بن عثمان بهن 
و واما الاعتبار الثالث وهو البركة، فلا شك أن الزكاة تبارك المال، ورب المال وهو داخل في الاعتبار

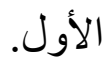
وأما الاعتبار الرابع وهو الددح، فباذل زكاة ماله

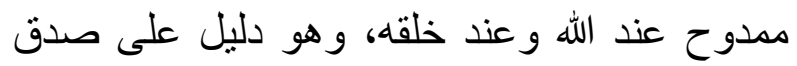
إيمان مخرجها، و هذا من أعظم ما يمدح به العبد. والزكاة اصطلاحاً: عرفها الحنفية بقولهم: التمليك بكانه

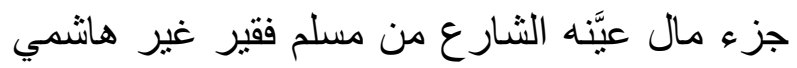

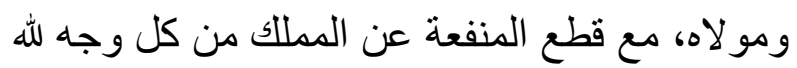
نعالى《) (0)

و هم يرون أن اسم الزكاة هو عبارة عن فعل

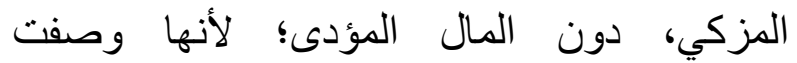
بالوجوب، والوجوب إنما هو من صفات الأفعال لا

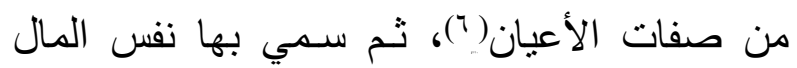

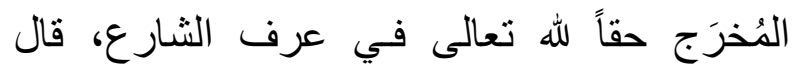

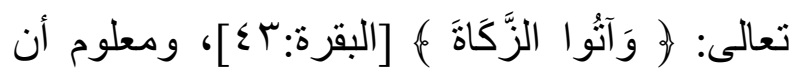
متعلق الإيتاء المال، أما في عرف فقاء الرهاء الأحناف

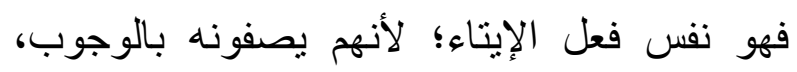

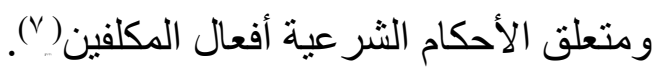

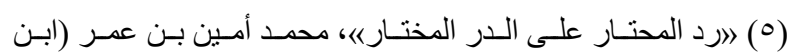

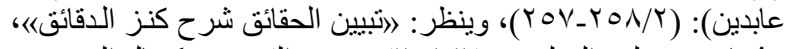

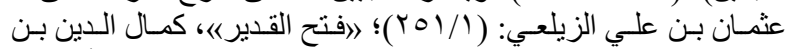

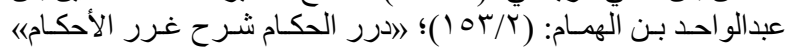

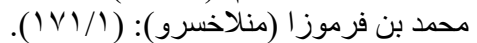

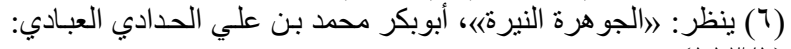
(1) $1 / 1)$

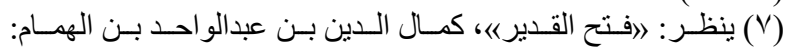
$(10 \mathrm{r} / \mathrm{r})$

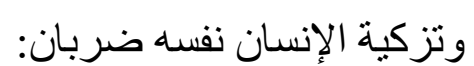
• أحدهما بالفعل: وهو محمود و إليه قصد بقوله:

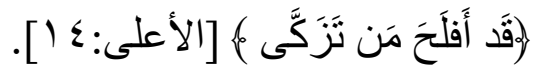
و والثاني بالقول: - كتزكية العدل غيره- وذللك مذموم أن يفعل الإنسان بنفسه وقد نهى الله تعالى

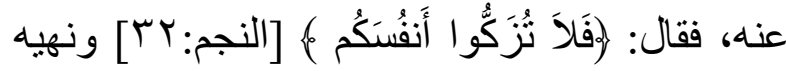
عن ذلك تأديب لقبح مدح الإنسان نفسه عقلاً وشر عاًر) ' (')

المطلب الثاني: تعريف الزكاة اصطلاحاً ترد الزكاة في الثرع بالاعنبارات التي مر ذكرها

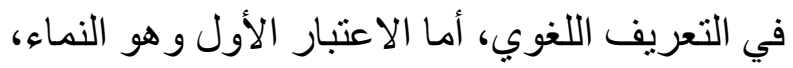
فلأن إخراجها سبب للنماء في المال، كما قال النبي

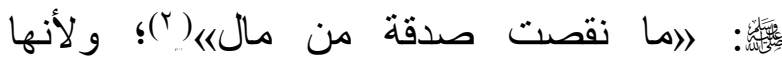
يضاعف ثوابها كما ورد أن الله يربي الصدقة، أو بمعنى أن الأجر بسببها يكثر أو بمعنى أن متعلقها الأموال ذات النماء كالتجارة والزراعة، أو لأنها تنمي الفقر اء. وأما الاعتبار الثاني وهو الطهارة، فلأنها طهرة للنفس من رذيلة البخل، وتطهير من الذنوب(")، وسمي المخرَج زكاة لأنه يزيد في المخرج منها ويطهره ويقيه الآفات (ء). 
وجاء في 》حاثية قليوبي/ قوله: 》المال مخصوص

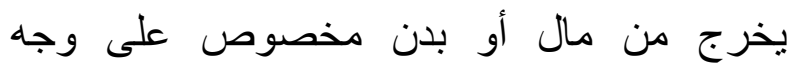

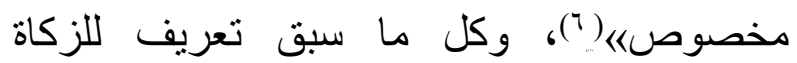
بالمعنى الاسمي، و عامة الثافعية يعرفونها كذللك،

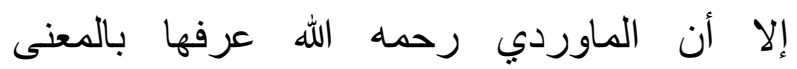
المصدري، فقال: إاسم صريح لأخذ شيء مخصوص من مال مخصوص، على أوصاف لاف

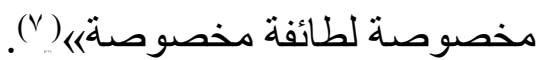
و عرفها الحنابلة بقولهم: 》احق واجب في مال مخصوص لطائفة مخصوصة في وقت مخصوصه( ^)، و عامة تعريفات الحنابلة تواردت على مثل ذللك(9)، وهو تعريف للزكاة بالمعنى الاسمي كما تقدم.

المطلب الثالث: تحرير محل النزاع

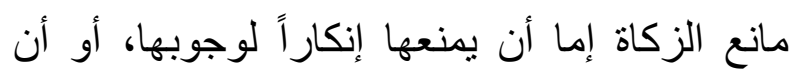

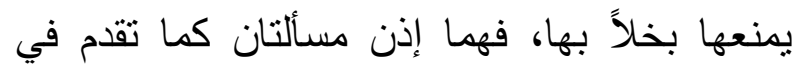

تارك الصلاة.

\section{المسألة الأولى: مهلة مانع الزكاة إنكاراً لوجوبها}

ذكر أهل العلم -رحمهم الله- أن من أنكر وجوب الزكاة جهالً به، وكان ممن يجهل ذللك إما لحداثة

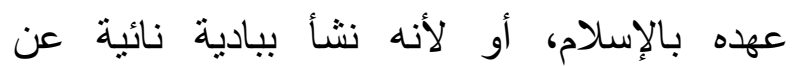

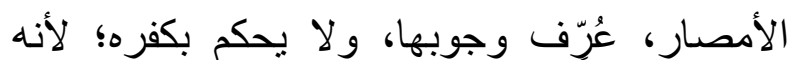

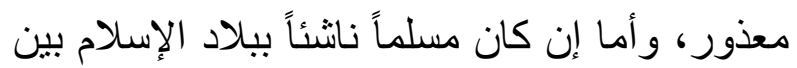

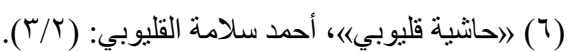

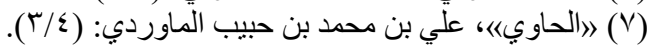

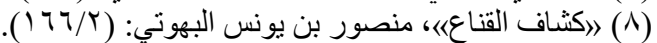

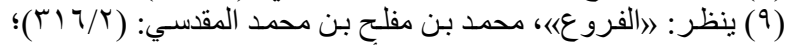

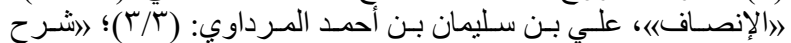

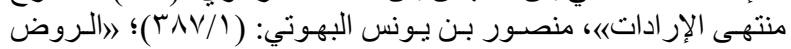

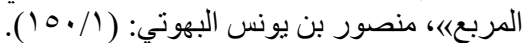

وذكر المالكية أن مصطلح الزكاة يحتمل المعنى

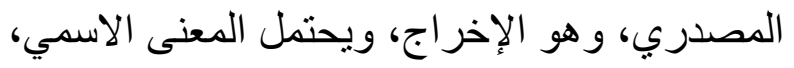

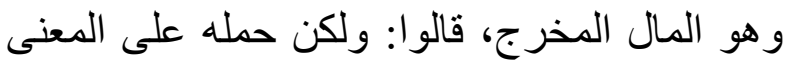
الدصدري أولى؛ لأن الوجوب من الأحكام التكليفية، و لا تكليف إلا بفعل اختياري(')، وقد تقدم مثل ذللك التك في تعريف الحنفية. و على ذللك فقد عرفها المالكية بالمعنى الاسمي

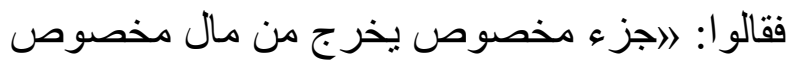

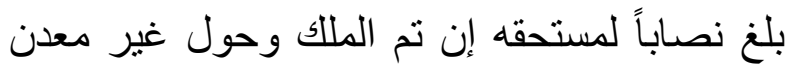

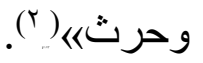
وأما بالمعنى المصدري فإنهم يعرفونها بقولهم:

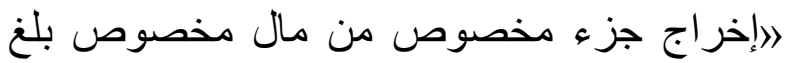
نصاباً لمستحقه إن تم الملك غير معدن وحرثي(").

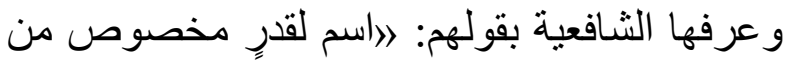
مال مخصوص، يجب صرفه لأصناف مخصوصة بشر ائط محددة) (\&). وقال في 》أسنى المطالب): 》اسم لما يخرج عن مال أو بدن على وجه مخصوص، سمي بذللك لأنه يطهر ويصلح وينمي ويمدح المخرج عنه ويقيه الآفاته (م).

(1) ينظر : (اشر ح مختصر خليل للخرشي)، محمد بن عبدالله الخرشي: . ( $\left.\left(\leq \Lambda_{-}\right) \leq V / T\right)$

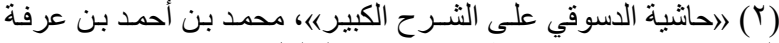

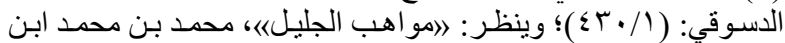

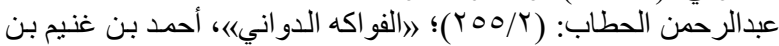

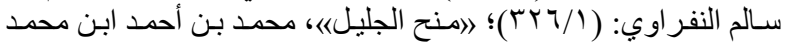

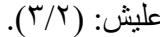

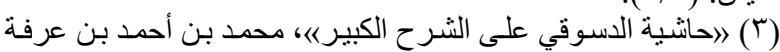

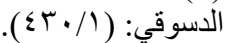

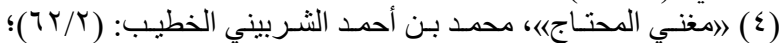

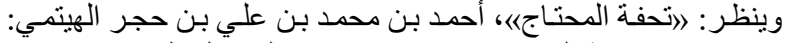

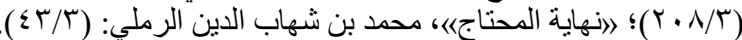

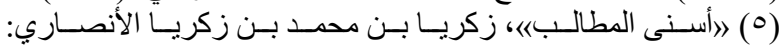

. ( 
كقريب عهد بإسلام، أو نشوئه ببادية بعيدة، بحيث

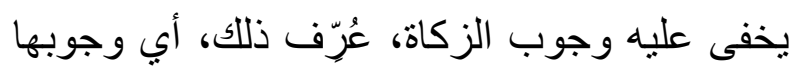

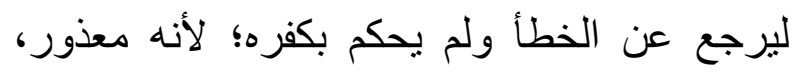
ونهي عن المعاودة لجحد وجوبها لزو ال عذره، فإن لئرة لآنه أصرَّ على جدد الوجوب بعد أن عُرف، أو كان

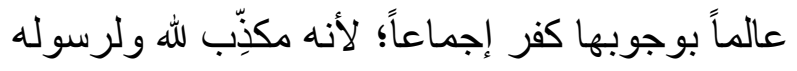

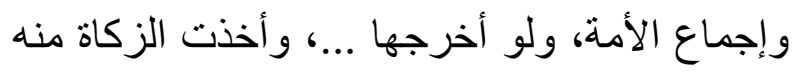

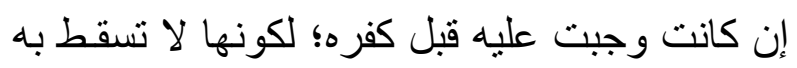

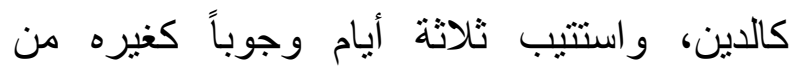

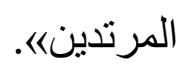
فالخلاصة أن من ترك الزكاة جحداً لوجوبها، بعد

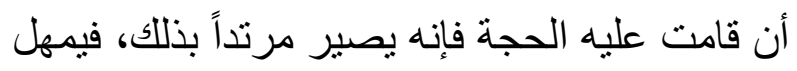
مهلة المرتد كما تقدم بحثه في مسألة (مهلة استتابة

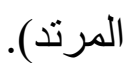

المسألة الثانية: مهلة مانع الزكاة بخلاً مع إقراره

بوجوبها اتفق أهل العلم -رحمهم الله تعالى- على أن مانع

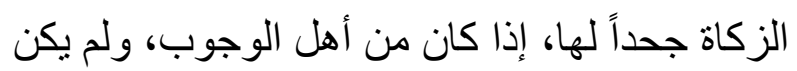

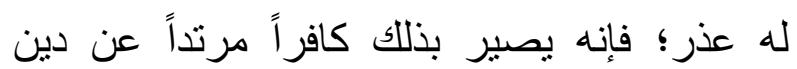
الإسلام، فيستتاب، فإن تاب و إلا قتل لردنه كما تقدم.

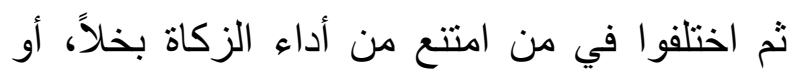

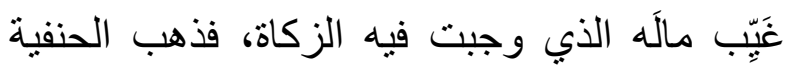

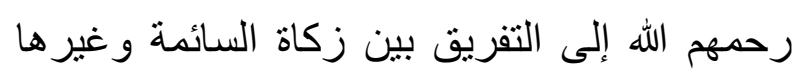
من الأمو ال الباطنة، فأما السائمة فللإمام أخذ زكاتها

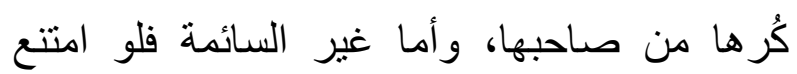

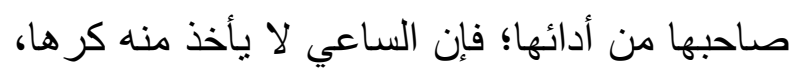

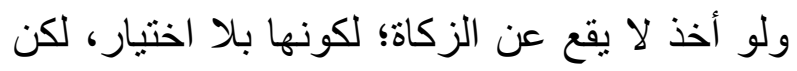
يجبره بالحبس ليؤدي بنفسه؛ لأن الإكراه لا يسلب الزات
أهل العلم، فهذا لا يعذر، بل هو مرتد، تجري عليه

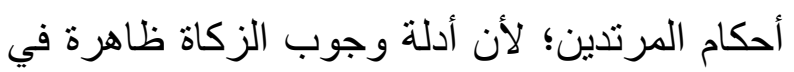

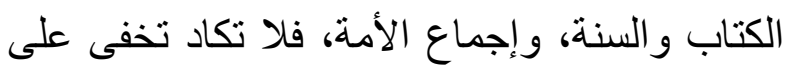
أحد ممن هذه حاله، فإذا جددها فإن ذلك لا يكون إلا لإنال

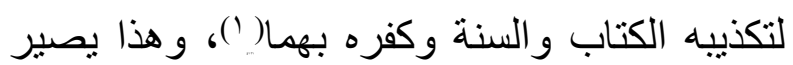
مرتداً عن الإسلام، وحكمه حكم المرتد في الاستتابة و القتل كما في المسألة الأولى من هذا البحث حثن. جاء في 》البحر الرائق《() قوله عن الزكاة: >افريضة محكمة قطعية أجمع العلماء على تكفير جاحدها《. وجاء في 》الفو اكه الدواني/() قوله: او أما الجاحد

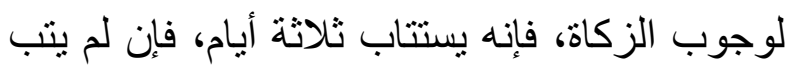
يقتل كفراً الز وجاء في 》انهاية المحتاجه|(") قوله عن الزكاة: |»....ومن ثم كانت أحد أركان الإسلام فيكفر جاحدها

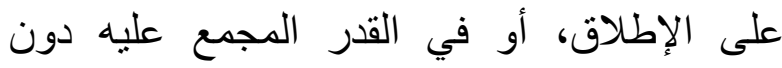

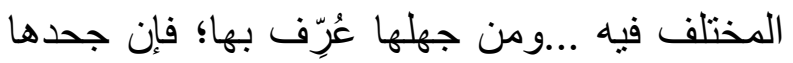
بعد ذللك كفر 《.

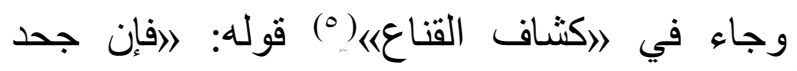
المسلم الحر المكلف وجوبها أي الزكاة ومثله يجهله

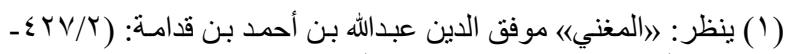

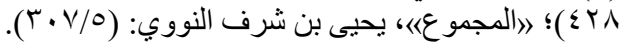

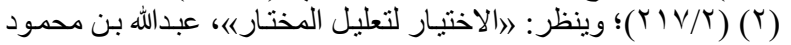

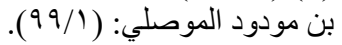

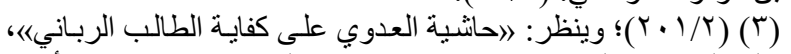

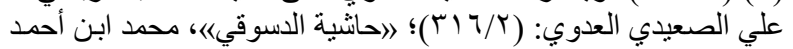
بن عرفة الدسوقي: (1/) (19) ).

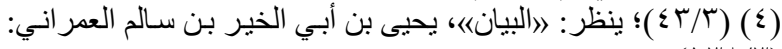

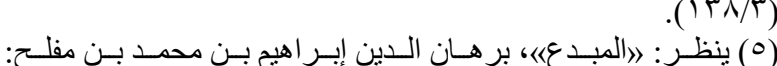




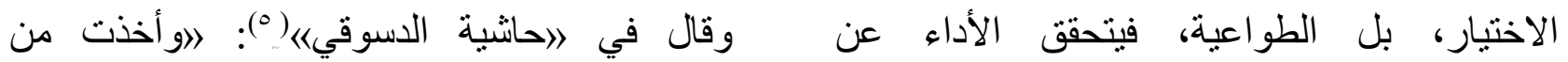

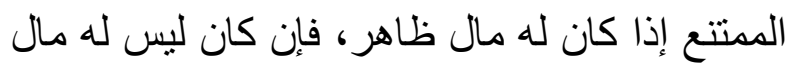

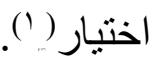

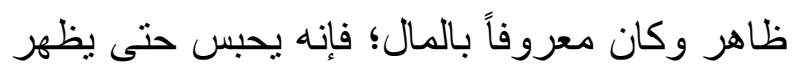
ماله «

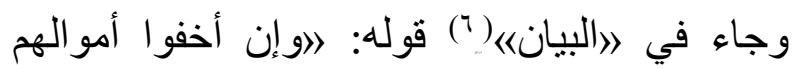

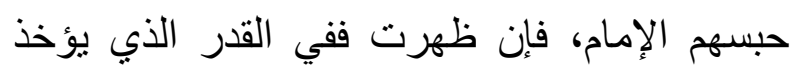

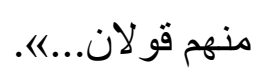

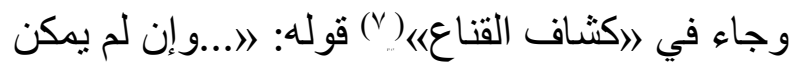
أخذها أب الزكاة بالتغييب أو غيره استتيب ثناثة أيام وجوباً؛ لأن الزكاة أحد مباني الإسلام، فيستتاب الزباب

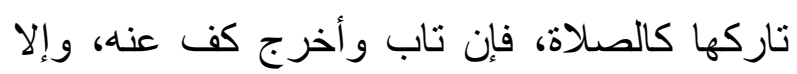

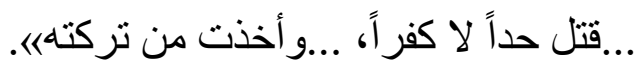

وحاصل أقوال الفقهاء المتقدمة في مانع الزكاة بخلاً مع إقراره بوجوبها تؤول إلى قولين: الأول: أنه يحبس حتى يؤدي بنفاره بوجسه، أو يظهر ماله الذي أخفاه، وهذا مذهب جمهور الفقهاء من الحنفية

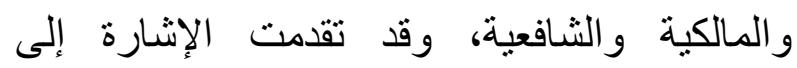
مذاهبهم. الثاني: أنه إن غيب ماله أو كتمه؛ فإنه يستتاب ثلاثة

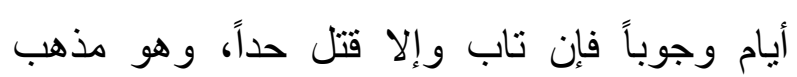
الحنابلة.

\section{المطلب الرابع: سبب الخلاف}

الذي يظهر لي أن السبب في الخلاف في المسألة

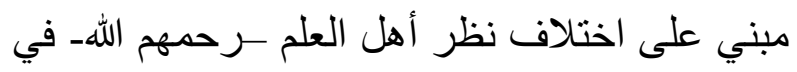

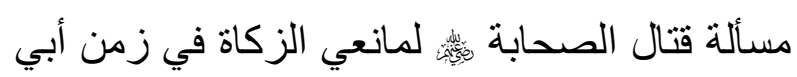

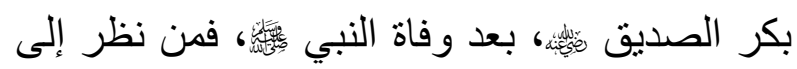

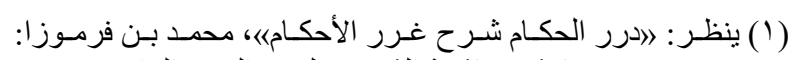

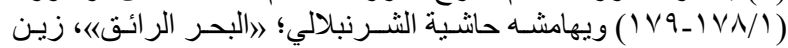

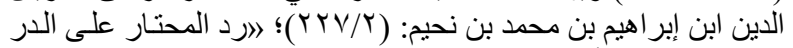

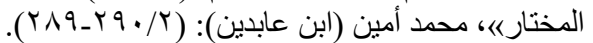

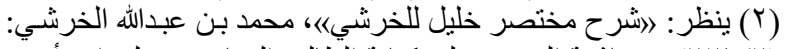

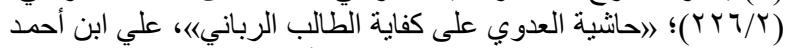

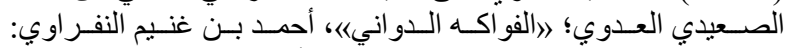

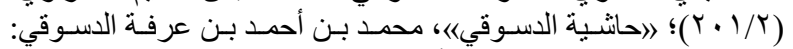

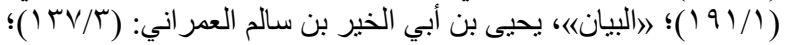

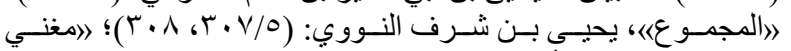

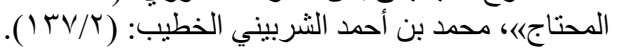

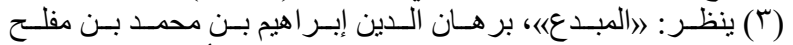

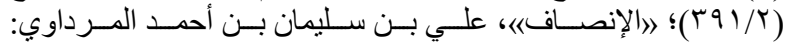

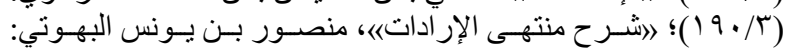
$(\varepsilon \leqslant \tau / 1)$ $($ ( $\vee \wedge / 1)(\varepsilon)$ 
فإنه يعزره بالحبس حتى يؤدي زكاته، أو يظهر ماله

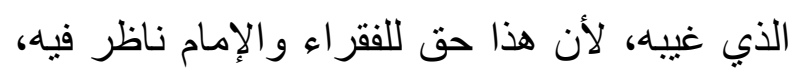

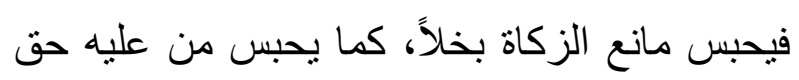

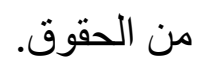
وأما القول بقتلك قياساً على قتتال الصحابة لمانعي

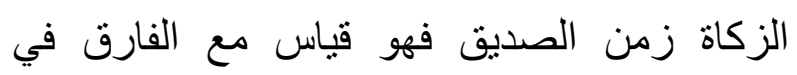

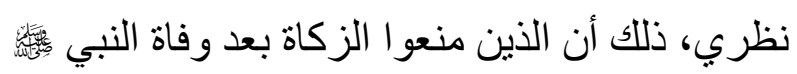
كان منهم من ارتد عن دينه، وكان منهم من بخل النل

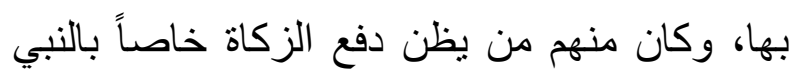

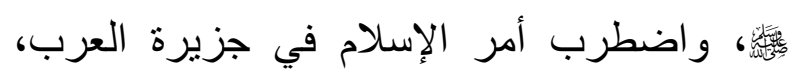

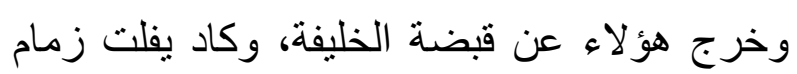

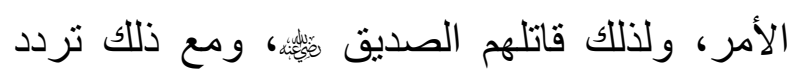

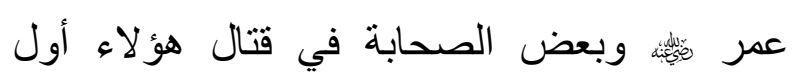

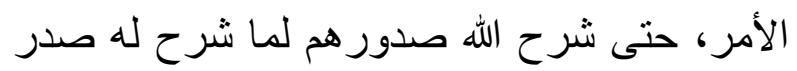

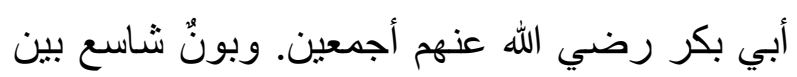

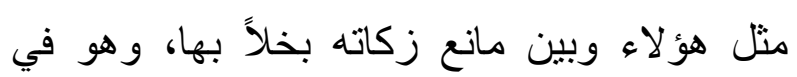
قبضة الإمام، ولم يقاتل على منعها.

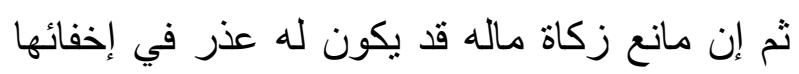

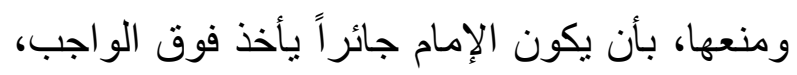

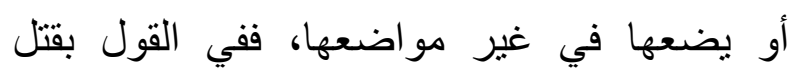
مخفيها ذريعة إلى تسلط الظلمة من الولاة على الى فئل

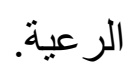
و الله تعالى أعلم.

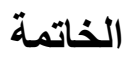

الحمد لله الذي بنعمته تتم الصالحات، والصلاة و السلام على أنشرف البريات، نبينا محمد و على آله وصحبه، ومن سار على نهجه واقتفى أثره إلى ولى لئل الممات.. و وبعد..
أن هؤلاء كانوا خارجين عن قبضة الإمام، ولذلك

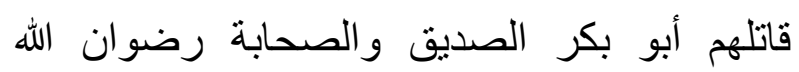

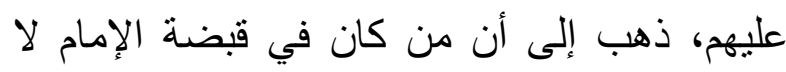
حاجة لقتاله، بل يحبس حتى يؤدي ما أوجبه الله عليه

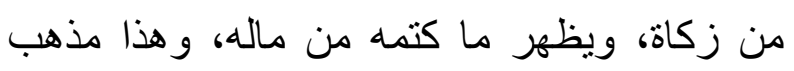
جمهور الفقهاء من الحنفية و المالكية و الثشافعية. و وأما من نظر إلى أن الزكاة أحد مباني الإسلام، الفهاءة

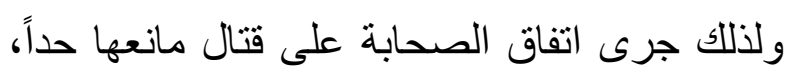
فذهب إلى أن كل من منع الزكاة بخلاً ؛ فإنه يستتاب؛ فإن تاب وأخرَج الزكاة وإلا قُتل هو الآخر حداً، و هذا مذهب الحنابلة.

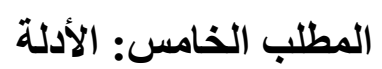
يمكن أن يستدل لقول الجمهور بأن الحبس لمخفي

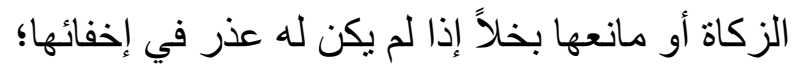

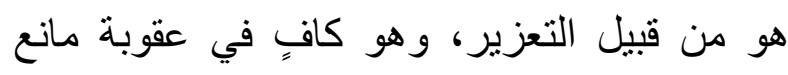
الزكاة ما دام في قبضة الإمام، ولم يقاتل عليها.

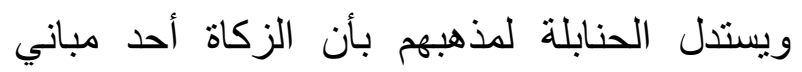

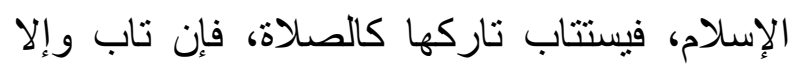
قتل؛ لاتفاق الصحابة على قتال مانعها حداً. ويمكن أن يناقش هذا الاستدلال بأن هذا إنما يكون

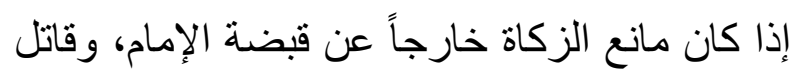

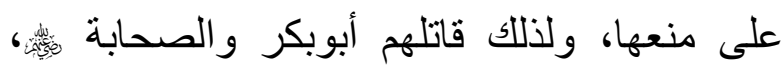
ونحن نقول به، أما إذا ظفر به الإمام وصار التهار في قبضته عزره بالحبس حتى يخرج زكاته.

المطلب السادس: الترجيح بعد التأمل العميق في المسألة، فإن الذي يظهر لي

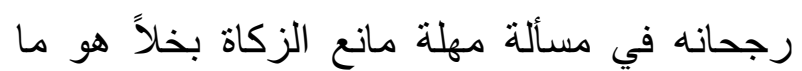
ذهب إليه الجمهور من أنه إذا كان في قبضة الإنهام 
ففي خاتمة بحثي هذا بمكنني أن أسجل النتائج حكم المرتد في الاستتابة والقتل، وهكا الحال في مانع الزكاة. و التوصبات التالية:

1- أظهر البحث أن جمهور أهل العلم ذهبوا إلى أنى قتل تارك الصلاة تهاوناً وكسلاً، على خلاف بينهم هل يقتل حداً أم كفر اً. 9- اختار الباحث القول بتعزير تارك الصغلاة تهاوناً بالحبس حتى يأتي بها. • 1 - استتتج الباحث أن السبب في الخلاف في مسألة مهلة تارك الصلاة تهاوناً وكسلاً مبني على الى اله اختلاف أهل العلم في أصل المسألة، وهو حكم تار كها تهاوناً. 11 - أظهر البحث أن جمهور أهل العلم يرون إمهال تارك الصلاة احتياطاً وصوناً للاماء.

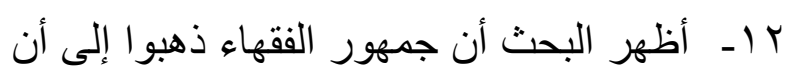
مانع الزكاة بخلاً، أو مَن غَيَّبَ ماله و أخفاه وهو في

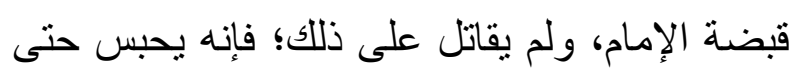

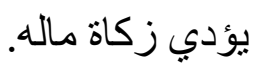

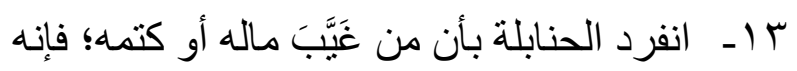

يستتاب ثثلاثة أيام وجوباً، فإن تاب و إلا قتل حداً. ع ا ـ استتنج الباحث أن السبب في الخلاف في مسألة مهلة مانع الزكاة هو القياس على تعامل

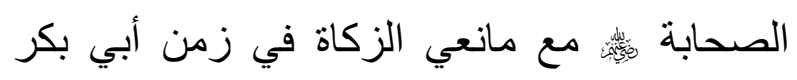
الصديق ن 10 ـ ـ رَجَّحَ الباحث مذهب الجمهور في مسألة مهلة مانع الزكاة بخلاً من أنه إذا كان في قبضة الإمام فإنه يعزر بالحبس حتى يؤدي زكاته، أو يُظهر مالَه

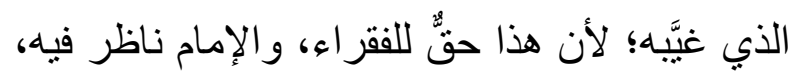

ا - أظهر البحث أن الأقضية الثرعية منها ما يكون على الفور دون إمهال، كالرد بالعيب، ومنها

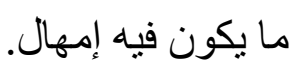
r - بين البحث إجماع أهل العلم على قتل المرتد

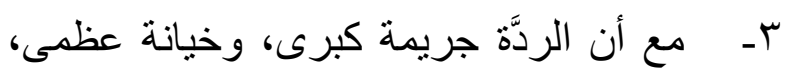
تستحق أقصى العقوبات، إلا أن البحث قد أظهر أن عامة أهل العلم رحمهم الله ذهبو ا إلى استتابة المرتد قبل قتله، و هذا دليل ظاهر وبر هان بين على دحض رها

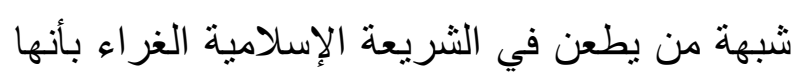
متشوفة لسفلك الدماء و إز هاق الأنفس. عـ - أظهر البحث أن جمهور العلماء يرون إمهال المرتد ثلاثة أيام لعله يتوب وير اجع أمر الله. 0ـ - أظهر البحث أن السبب في اختلاف الفقهاء في إمهال المرتد ثناثة أيام من عدمه هو اختلافهم

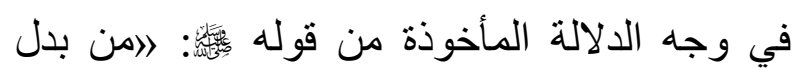
دينه فاقتلوهاء، فمن قال بقتله في الحال بعد الاستتابة

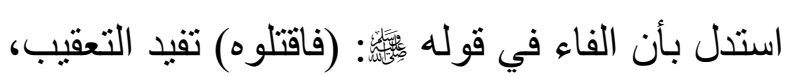
فيستتاب فإن تاب وإلا قتل، ومن ذهب إلى إمهاله جعل الأمر بالقتل بعد الاستتابة ثلاثة أيام؛ للآثار الواردة في المسألة. 7- أظهر البحث أن تارك الصداة إذا كان جاحداً

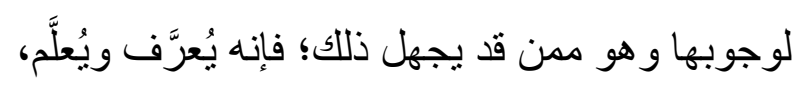
ولا بحكم بكفره لأنه معذور، و هكذا الحال في مانع

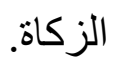
- - أما إذا كان ممن لا يجهل ذللك؛ فإنه لا بعذر

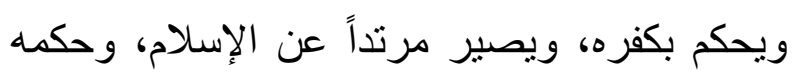




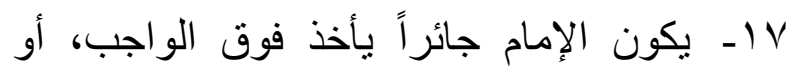
يضعها في غير مواضعها؛ ففي القول بقتل مخفيها ذريعة إلى تسلط الظلمة من الو لاة على رعاياهم. 1 أـ أوصي بإكمال بحث مسائل الأقضية والأحكام التي تجري المهلة فيها ثلاثة أيام بحثناً 9 اــ مقارناً؛ للأهمية القصوى التي تمثلها مثل هذه المسائل للقاضي الثرعي. و الله أسأل أن يسلك بي سبيل الهاى و الرشاد، و أن

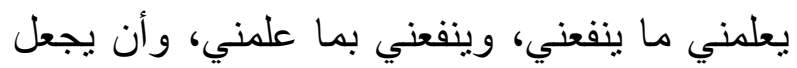
أعمالي خالصةً لوجهه الكريم. و الله أعلم، وصلى الله على نبينا محمد و على آله لهاهله وصحبه وسلم تسليماً كثير أ،، اله

الأعلام. الزركلي: خير الدين ابن محمود بن محمد

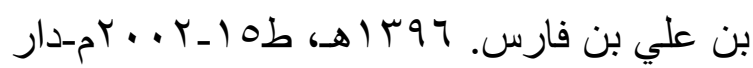

$$
\text { العلم للملابين - بيروت. بن فين. }
$$

الإنصاف. المرداوي: علي بن سليمان. 110هـه،

$$
\text { طب-د.ت_دار الكتاب الإسلامي. }
$$

البحر الرائق شرح كنز الدقائق. ابن نجيم: زين الدين

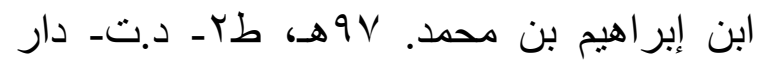

$$
\text { الكتاب الإسلامي. }
$$

بدائع الصنائع في ترتيب الثرائع. الكاساني: أبو بكر الإنيا

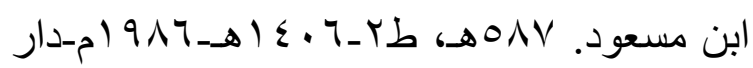

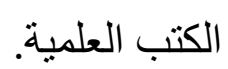

بداية المجتهد ونهاية المقتصد. ابن رشد: محمد ابن

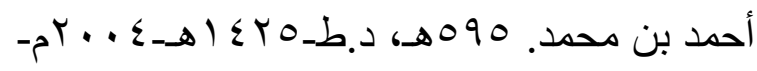

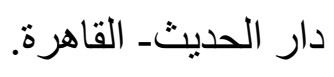

فيحبس مانع الزكاة بخلاً، كما يحبس مَنْ عليه حقٌ

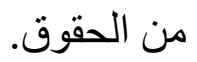
17 اــ القول بقتل مانع الزكاة بخلاً قياساً على قتل

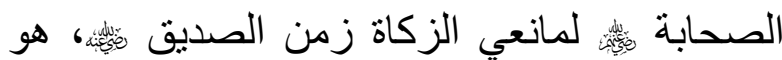

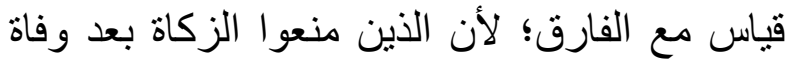

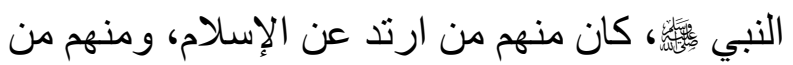

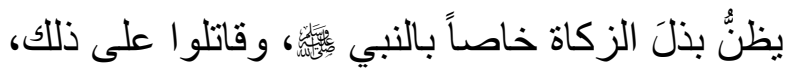
و واضطرب أمر الإسلام في جزيرة العرب، وخرجوا

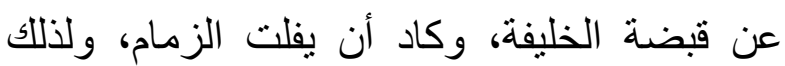
قاتلهم الصديق ثئئ، وفرقُ كبير بين تلك الحال وحال

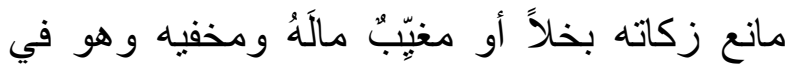

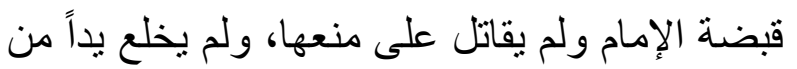
طاعة. ثم إن مانع زكاة ماله قد يكون لله عذرّ في إخفائهُ ومنعِها؛ كأن

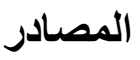

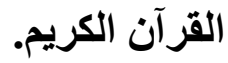
الاختيار لتعليل المختار. الموصلي: عبدالله بن

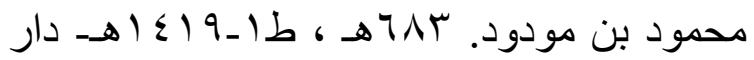
الخير-دمشق- تحقيق: علي عبدالحميد - محمد و هبى سليمان. أسنى المطالب شرح روض الطالب. الأنصاري: أبو

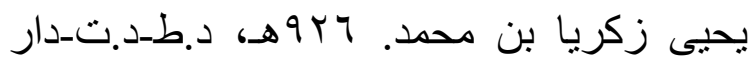
الكتاب الإسلامي - بيروت. 
تهذيب الأسماء واللغات. النووي: يحيى ابن شرف.

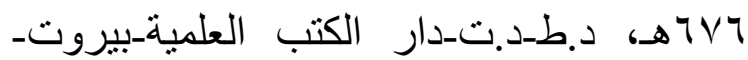
تحقيق: مصطفى عبدالقادر عطا. الجامع الصحيح (سنن الترمذي) الترمذي: محمد ابن عيسى.

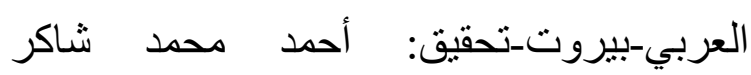

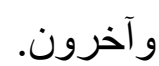

الجوهرة النيرة. العبادي: أبوبكر ابن علي بن محمد

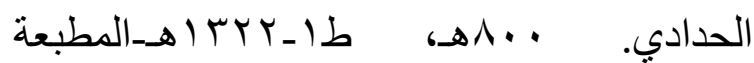

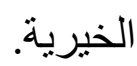

حاثية البجيرمي على شرح الخطيب. البجيرمي:

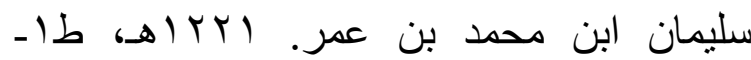
ا ا اهـ ـ دار الكتب العلمية- بيروت. حاثية الدسوقي على الثرح الكبير. الدسوقي: محمد

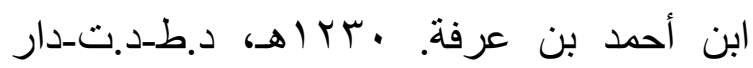
إحياء الكتب العربية ـ القاهرة. حاثية الثرنبلالي على درر الحكام شرح غراء الثراء الأحكام. الثرنبلالي: حسن ابن عمار. 79 . 1 أهـ، د.ط-د.ت_دار إحياء الكتب العربية. حاثية العدوي على شرح مختصر خليل للخرشي.

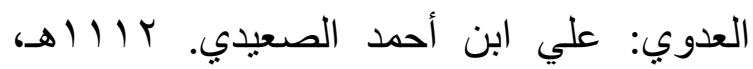

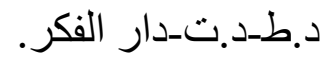
حاثيتا قليوبي وعميرة على شرح المحلي على الىكر. المنهاج للنووي. القليوبي: أحمد ابن أحمد بن النداعيا سلامة + البرلسي: شهاب الدين أحمد، الثهير الثين

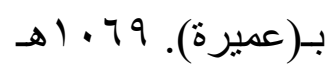

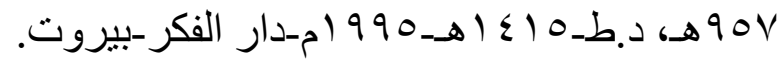

البيان. العمراني: يحيى بن أبي الخير بن سالم ابن

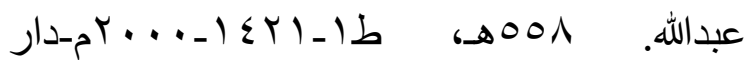
المنهاج.

تاج العروس من جواهر القاموس. الزبيدي: محمد ابن محمد بن عبدالرزاق الحسيني المرتضى.

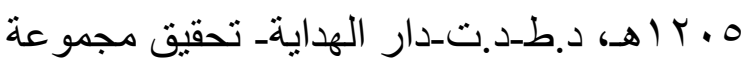

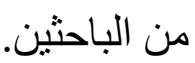
التاج والإكليل لمختصر خليل. الموَّاق: محمد ابن

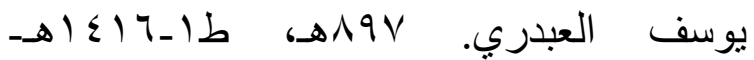
ـ99 ام-دار الكتب العلمية.

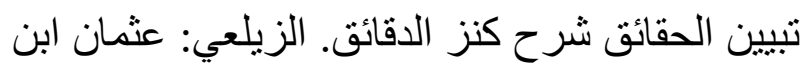

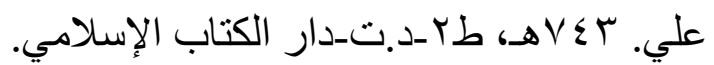

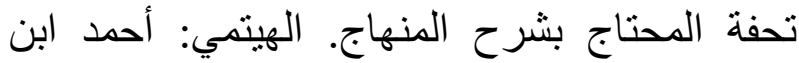

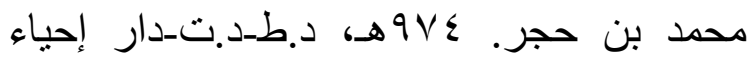
التر اث العربي. ترتيب المدارك وتقريب المسالك لمعرفة أعلام مذهب مالك. السبتي: عياض ابن موسى بن

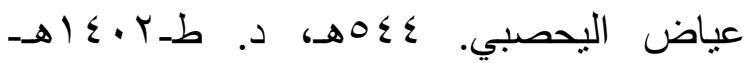
ra19 ام_منشورات وزارة الأوقاف و الثؤون الإسلاميةـ المملكة المغربيةـ تحقيق: سعيد أحمد التحان

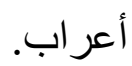
التلخيص مطبوع مع مستدرك الحاكم النيسابوري.

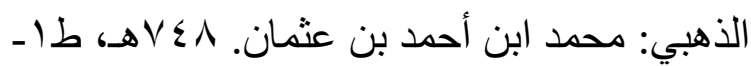

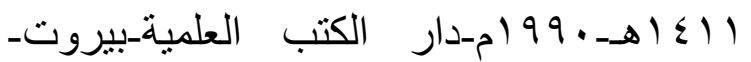
تحقيق: مصطفى عبدالقادر عطا. التلخيص الحبير. العسقلاني: أحمد ابن علي بن حجر. 10 هــ، د.طـد.ت-مؤسسة قرطبة. 
سنن الدارقطني. الدارقطني: علي ابن عمر.

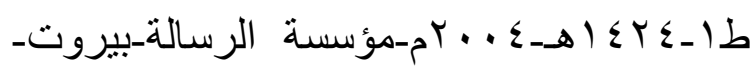
لبنان-تحقيق: شعيب الأرنؤوط وآخرون. سنن أبي داود. السجستاني: سليمان ابن الأشعث.

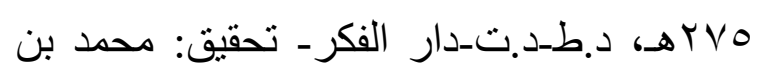

$$
\text { محيي الدين عبدالحمبد. }
$$

السنن الكبرى. البيهقي: أحمد ابن الحسين بن علي.

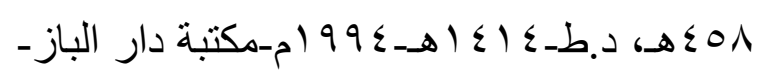

مكة المكرمة_تحقيق: محمد عبدالقادر عطا.

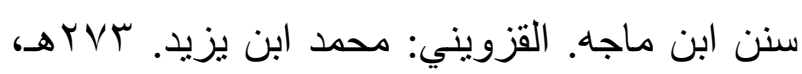

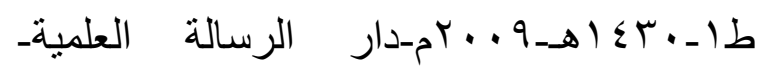
تحقيق: شعيب الأرنؤط و آخرون. سنن النسائي. النسائي: أحمد ابن شعيب بن علي.

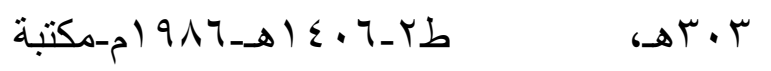
المطبو عات الإسلامية_حلب_تحقيق: عبدالفتاح أبو غدة.

سير أعلام النبلاء. الذهبي: محمد بن أحمد ابن

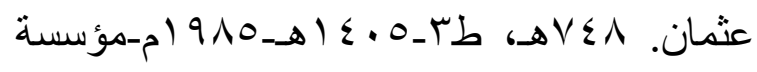
الرسالة-بيروت-تحقيق مجموعة من المحققين

$$
\text { بإثر اف الثيخ شعيب الأرنؤوط. }
$$

شجرة النور الزكية في طبقات المالكية. مخلوف:

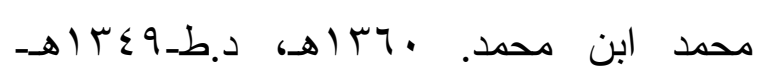
المطبعة السلفية ومكتبتها_القاهرة. شرح حدود ابن عرفة. الرصاع: محمد بن قاسم

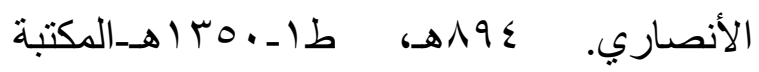
العلمية. شرح مختصر خليل للخرشي. الخرشي: محمد ابن عبدالله. 1 • 1 اهـ، د.ط-د.ت-دار الفكر -بيروت.
الحاوي الكبير. الماوردي: علي ابن محمد بن حبيب.

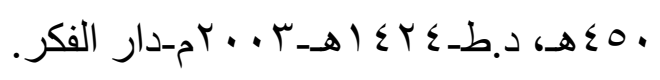
حكم تارك الصلاة. الألباني: محمد ناصر الدين.

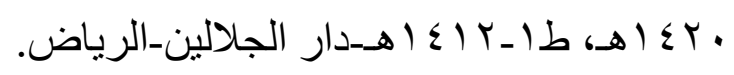
الديباج المذهب في معرفة أعيان علماء المذهب. ابن فرحون: إبراهيم ابن علي بن محمد. 999 هـ

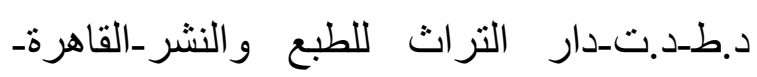
تحقيق الدكتور : محمد الأحمدي أبو النور. درر الحكام شرح غرر الأحكام. منلاخسرو: محمد

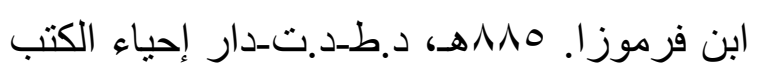
العربية.

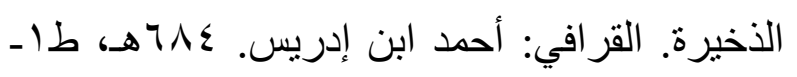

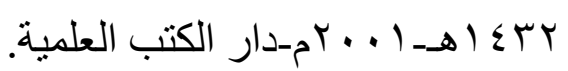
رد المحتار على الدر المختار في شرح تنوير الأبصار (حاثية ابن عابدين). ابن عابدين: محمد

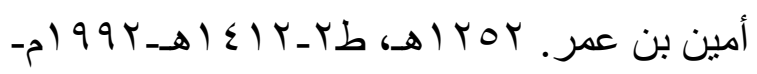
دار الفكر -بيروت. الروض المربع. البهوتي: منصور تبن يونس بن

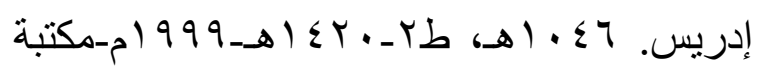

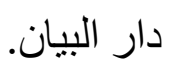
سبل السلام. الصنعاني: محمد ابن إسماعيل بن

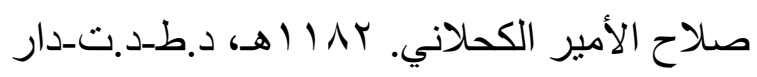
الحديث. سلسلة الأحاديث الصحيحة. الألباني: محمد ناصر

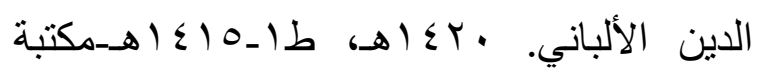
المعارف للنشر و التوزيع - الرياض. 
المعرفة-بيروت-ترقيم: محمد فؤاد عبدالباقي، أشرف على طباعته: محب الدين الخطبب، عليه تعليقات العلامة: عبدالعزيز بن عبدالله بن باز . فتح القدير (شرح الهداية). ابن الهمام: كمال الدين

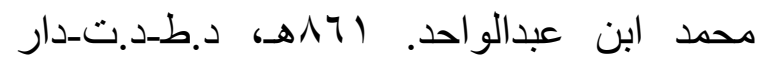
الفكر. فتح الوهاب شرح منهج الطلاب وبهامشه حاثية

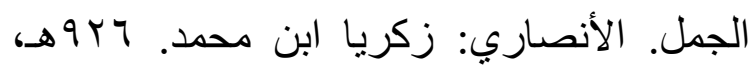

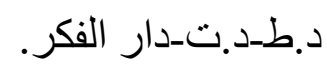

الفروع. المقدسي: محمد ابن مفلح. بآVه، طع-

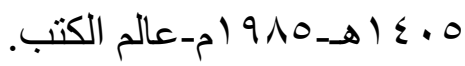
الفواكه الدواني على رسالة ابن أبي زيد القرواني. النفراوي: أحمد بن غنيم ابن سالم.

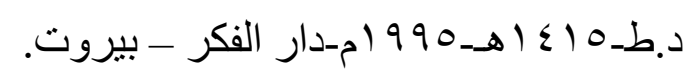
كثاف القناع عن متن الإقناع. البهوتي: منصور ابن

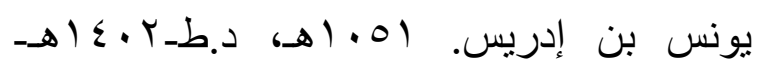
r 9 ام - دار الفكر - و عالم الكتب. كفاية الطالب الرباني وبهامشه حاثية العدوي. المالكي: علي بن محمد ابن محمد بن محمد ابن

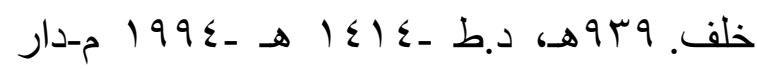
الفكر.

لسان العرب. ابن منظور : محمد ابن مكرم. I VII Iه، طا -د.ت-دار صسادر-بيروت. المبدع. ابن مفلح: إبراهيم ابن محمد بن عبدالله.

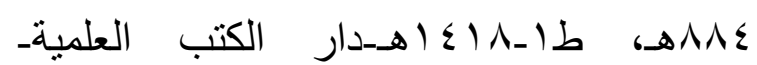
بيروت_لبنان.
شرح معاني الآثار. الطحاوي: أحمد ابن محمد بن

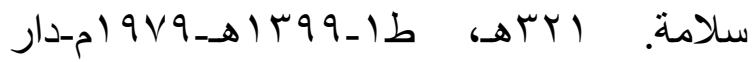

$$
\text { الكتب العلمية. }
$$

الثرح الممتع على زاد المستقنع. العثيمين: محمد ابن

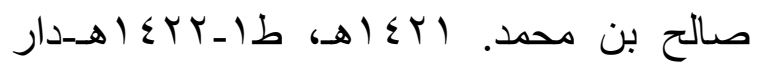
ابن الجوزي.

شرح منتهى الإرادات. البهوتي: منصور ابن يونس

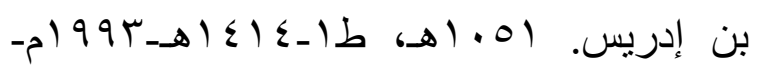

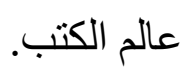
الصحاح. الجوهري: إسماعيل ابن حماد. بوسهـ،

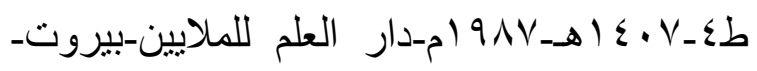
تحقيق: أحمد عبدالغفور عطار. صحيح البخاري. البخاري: محمد ابن إسماعيل.

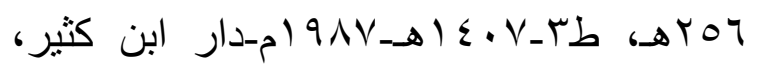
اليمامةـ بيروتـ تحقيق: د.مصطفى ديب البغا. صحيح مسلم. النيسابوري: مسلم ابن الحجاج

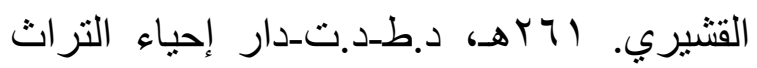
العربي-بيروت-تحقيق: محمد فؤاد عبدالباقي. الصلاة وحكم تاركها. ابن القيم: محمد ابن أبي بكر

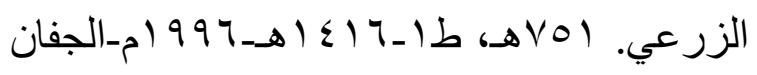
و الجابي- دار ابن حزم-قبرص-بيروت- تحقيق:

$$
\text { بسام عبدالو هاب الجابي. }
$$

طبقات الثافعية الكبرى. السبكي: عبدالوهاب ابن

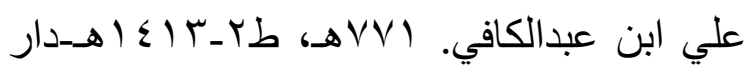
هجر للطباعة و النشر و التوزيع-تحقيق: د.محمود محمد الطناحي، د.عبدالفتاح محمد الحلو. فتح الباري بشرح صحيح البخاري. العسقلاني: أحمد

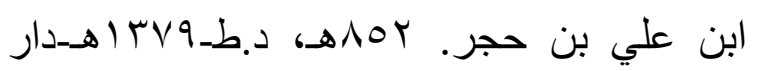


المغرب في ترتيب المعرب. المطرزي: ناصر الدين

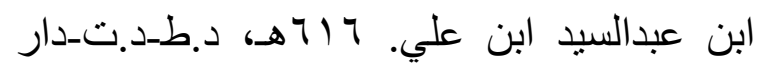
الكتاب العربي.

المغني. المقدسي: عبدالله ابن أحمد بن قدامة.

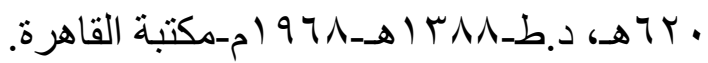
مغني المحتاج إلى معرفة ألفاظ المنهاج. الثربيني:

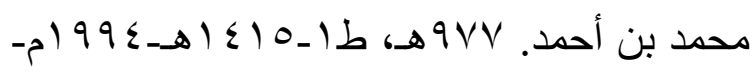
دار الكتب العلمية.

المفردات في غريب القرآن. الأصفهاني: الحسين ابن

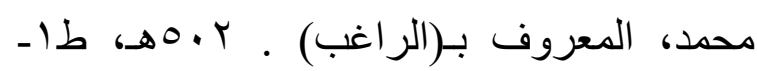

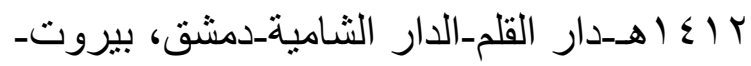
تحقيق: صفو ان عدنان الداودي. مقاييس اللغة. ابن فارس: أحمد ابن فارس بن زكريا.

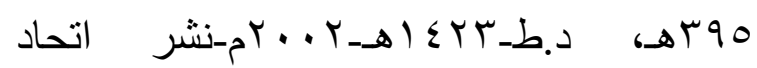
الكتاب العربي-تحقيق: عبدالسلام محمد هارون. المقدمات الممهدات. القرطبي: محمد بن أحمد ابن

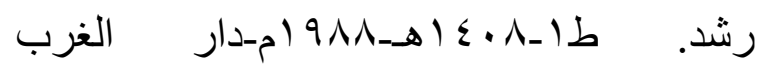
الإسلامي. المنتقى شرح الموطأ. الباجي: سليمان

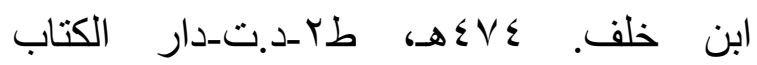
الإسلامي_القاهرة. منح الجليل شرح مختصر خليل. عليش: محمد بن

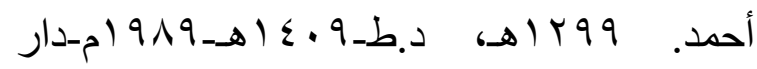
الفكر. مواهب الجليل شرح مختصر خليل. الحطاب: محمد

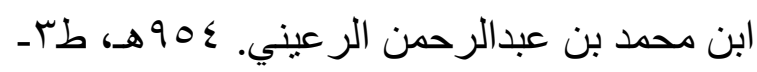

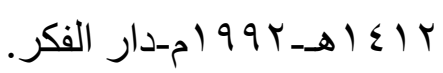

$$
\text { المبسوط. السرخسي: معد ابن أحمد بن أبي }
$$

مجمع الأنهر في شرح ملتقى الأبحر. شيخي زاده: عبدالرحمن بن محمد ابن سلمان. VA • ا هـ، د.طـ د.ت-دار إحياء التراث العربي. المجموع شرح المهذب. النووي: يحيى ابن شرف.

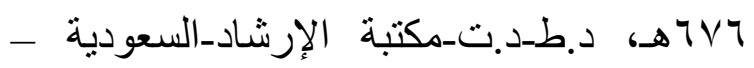

ومكتبة المطيعي. مجموع الفتاوى. ابن تيمية: تقي الدين أحمد بن

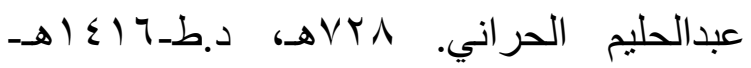
990 (م-نشر مجمع الملك فهد لطباعة المصحف الثريف_المدينة النبوية_المملكة العربية السعودية. المحلَّى. ابن حزم: علي ابن أحمد بن سعبد. 07 ؛هـ، د.طـد.ت_دار الكتب العلمية-بيروت. المستدرك على الصحيحين ومعه تعليقات الذهبي في التخليص. النيسابوري: الحاكم محمد بن عبدالله

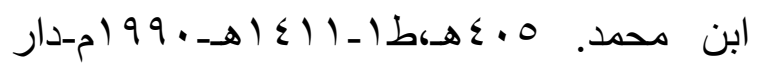
الكتب العلمية - بيروت_تحقيق: مصطفى عبدالقادر عطا. مسند الإمام أحمد. الثيباني: أحمد ابن محمد بن

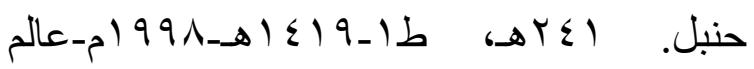
الكتب-بيروت-تحقيق: مصطفى عبدالقادر عطا. المصباح المنير في غريب الشرح الكبير. الفيومي: أحمد ابن محمد بن علي المقري. • VVه، د.طـ

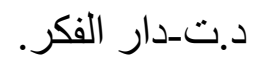




$$
\begin{aligned}
& \text { الموسوعة الفقهية. جماعة من العلماء. ـطهـ نصب الراية في تخريج أحاديث الهداية. الزيلعي: }
\end{aligned}
$$

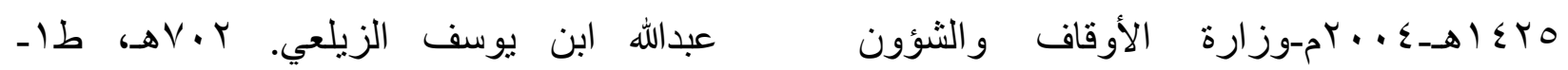

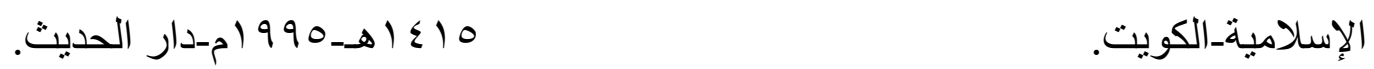

$$
\begin{aligned}
& \text { موطأ الإمام مالك. الأصبحي: مالك ابن أنس بن نهاية المحتاج إلى شرح المنهاج. الرملي: أحمد بن }
\end{aligned}
$$

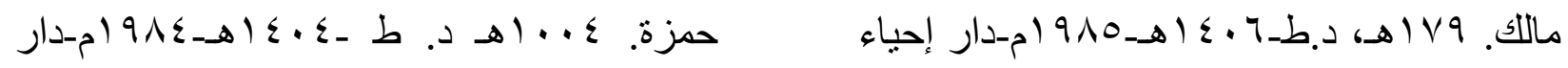

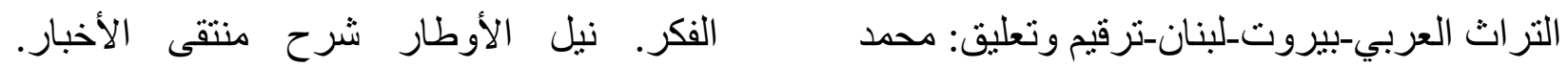

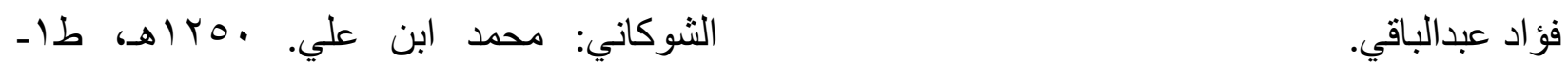

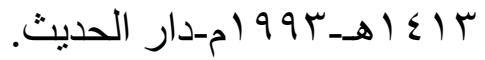

\title{
The judgements that can have three days time limit: the time limit of the apostate, the time limit of the neglected prayer, the time limit of the preventer of zakat.
}

\author{
Dr. Khalid Salem Saleh Al-Safri \\ King Abdulaziz University
}

This is a research entitled: (the interest transmitted concept, pilgrimage and controls), divided into a preface and three investigations, showed in the preamble relationship of the interest of Islamic legislation, and divisions of interest in various considerations of scientists, and then I showed in the first topic the concept of interest transmitted language and terminology, The interest sent starting with the liberation of the dispute in which then mention the words and attributed to the leaders and then the cause of the dispute and then the arguments and evidence and then the quality of the dispute, and listed in the third and final controls the interests sent and work.

I ask Allaah to benefit from this research and provide us with useful knowledge and good deeds. 